SCRIBERE VERSVS:

PRESENTACIÓN GRÁFICA DEL LENGUAJE VERSIFICADO *

J. LUQUE MORENO
Univ. de Granada

PREÁMBULO.

Aun tratándose de versos naturalmente destinados a la ejecución oral, la representación escrita de los mismos (scribere uersus ${ }^{1}$ ) aparece desde antiguo naturalizada en el mundo griego y romano; una larga tradición de labor filológica sobre los textos que transmitían las obras de los antiguos poetas así lo acredita. Pues bien, es en este campo de la escritura de los versos donde aquí nos vamos a situar, proponiendo unas reflexiones sobre sus peculiares problemas.

La cuestión, que evidentemente sólo vamos a plantear en sus líneas generales, tiene una doble vertiente, pues, si, de un lado, engarza con la compleja problemática general de la articulación del lenguaje, y más en concreto del lenguaje versificado, de otro lado, conecta con los no menos intrincados problemas de la escritura, es decir, de la representación gráfica de la comunicación vocal, oral, lingüística sobre todo, pero también musical.

En el primer sentido, se hace, por tanto, necesario tomar conciencia de la

* Este trabajo se enmarca dentro del Proyecto de Investigación HUM 2005 - 02893 / FILO, del Ministerio de Educación y Ciencia.

1 Hor., Epist. II 1,111 ipse ego, qui nullos me adfirmo scribere uersus. Tal como se expresan desde antiguo los romanos, dan a entender que para ellos esto de escribir los versos era algo natural: Lucr. I 24 te sociam studeo scribendis uersibus esse; Cic., Verr. II 3,77 de qua muliere uersus plurimi supra tribunal et supra praetoris caput scribebantur; Cat. L 4 scribens uersiculos uterque nostrum $\|$ ludebat numero modo hoc modo illoc; Hor., Epod. XI 1.s Petti, nihil me sicut antea iuuat $\|$ scribere uersiculos amore percussum graui; Hor., Sat. I 9,24 ... nam quis me scribere pluris \|| aut citius possit uersus?; Ov., Trist. IV 10,26 et quod temptabam scribere uersus erat.; Mart. I 35,1 Versus scribere me parum seueros. 
naturaleza rítmico-métrica, musical en último término, del lenguaje versificado y tener mínimamente clara la entidad de las unidades que habitualmente se reconocen en su articulación: el pie, el metro, el comma, el colon, el período o verso, la estrofa, etc.; una serie de conceptos y términos no siempre claramente definidos ni en la práctica de los versificadores antiguos ni en el lenguaje técnico de los antiguos artígrafos ${ }^{2}$.

Desde la otra vertiente se hace sentir aquí de lleno el lento y difícil proceso de la representación gráfica de los componentes prosódicos, suprasegmentales, del habla: el tono, la intensidad, la duración; factores todos ellos importantes en la comunicación vocal, pertinentes incluso a veces en determinados sistemas lingüísticos, pero no reflejados sistemáticamente en la escritura alfabética, que, en principio, sólo alcanza a las letras, a los fonemas, es decir, a los componentes tímbricos del sonus uocis, que son sobre todo los que caracterizan dichos fonemas o letras. Al abordar, por tanto, la cuestión de la representación gráfica del verso, nos adentramos en terrenos muy próximos al de la grafía de los prosodemas (los que afectan a las sílabas y las palabras: el acento, la cantidad, la aspiración, etc. y los que afectan a las frases: la entonación, las "pausas" que delimitan las unidades del habla, etc.) y no lejanos del de la representación escrita de la música ${ }^{3}$. Todo ello, además, en una escritura como la antigua, que, en cuanto que habitualmente destinada a la lectura en voz alta, se veía necesitada de signos que orientaran al lector en su función de reconcer ( $\left.\alpha{ }^{\prime} \alpha \dot{\gamma} v \omega \sigma 1 \varsigma^{4}\right)$ y transmitir al auditorio no sólo el

2 De las únidades menores, el pie o compás y su posible valor funcional como metro, ya me he ocupado en otras ocasiones (Luque 1994, 1995); en torno al comma / colon giran varios trabajos míos ya publicados (Luque 1998, 1999, 2001, 2002, 2003, 2004) y algunos otros más que, al igual que otros tantos consagrados a las unidades superiores, aún no han visto la luz.

3 Cuestiones sobre las que espero vean pronto la luz en la Universidad de Granada mis libros Accentus: el canto del lenguaje y Puntos y comas, dedicados a la prosodia, respectivamente, de la palabra y de la frase y a su representación gráfica.

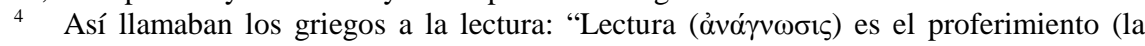

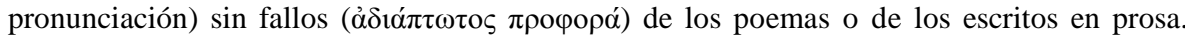
Hay que leer de acuerdo con la interpretación (con la actuación: $\kappa \alpha \theta^{\prime}$ vं

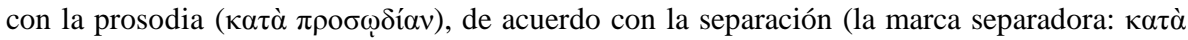
$\delta 1 \alpha \sigma \tau \mathrm{o} \lambda \eta \dot{\eta} v)$ ": Dion. Thrac., T $\varepsilon \dot{\chi} \vee \eta \S 2$. - Lectura que era la primera de las seis partes que el

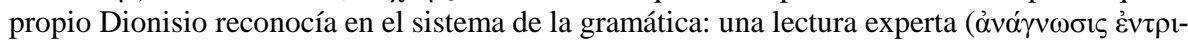

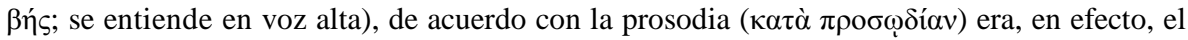

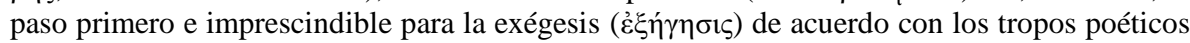

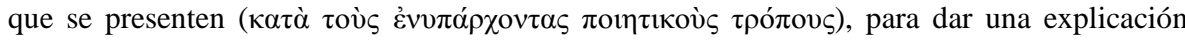

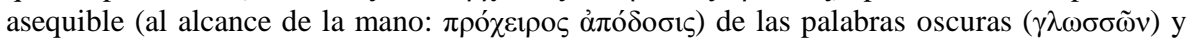

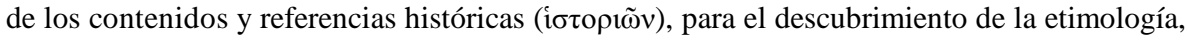

EMERITA (EM) LXXIII 2, julio-diciembre $2005 \quad$ pp. 303-351 ISSN 0013-6662 
contenido lógico-semántico del texto sino también, y en estrecha conexión con ello, la correcta entonación y articulación rítmica del mismo.

Interesado, por tanto, en dicha entonación y articulación, me voy a centrar en las unidades rítmico-métricas superiores, el verso, la estrofa, etc. y, más exactamente, en la grafía de dichas unidades. Prescindo por completo de su entidad rítmico-métrica ${ }^{5}$; no es ésta ocasión para ocuparse de ella, como tampoco lo es para entrar en los problemas generales de la grafía de los prosodemas.

\section{EL VERSO.}

El verso, sin embargo, y, más en concreto, los términos con los que se lo designa sí dan pie para hacer algunas consideraciones, sin salir del territorio que acabo de marcar; es más, se diría que invitan incluso a hacerlas.

En efecto, dentro de todo el sistema de unidades que tradicionalmente se reconocen en la articulación del lenguaje versificado, la unidad "verso", $\sigma \tau i ́-$

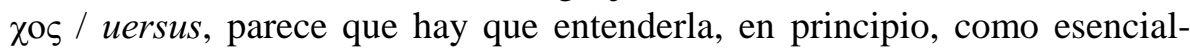
mente métrica; no parece que como tal unidad se remonte a la anterior fase musical de dicho sistema, ni pertenece tampoco a la posterior herencia del mismo sistema en el campo de la retórica; como es, por ejemplo, el caso del concepto y del término "período". El verso se presenta, pues, como algo exclusivo de la métrica ${ }^{6}$; es más, los nombres con que lo designaron tanto los griegos como los romanos parecen, de entrada, apuntar a una métrica que opera con el lenguaje versificado no tanto en su genuina oralidad sino en su representación escrita.

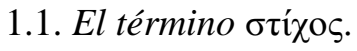

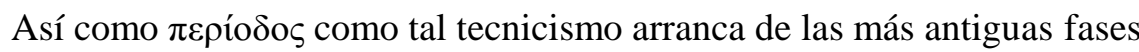
de la praxis (y luego de la teoría) musical, de las evoluciones circulares en un

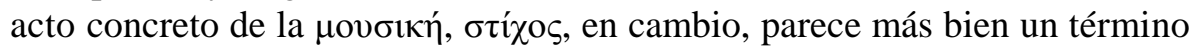

para el establecimiento de la analogía, es decir, de los patrones regulares y, por fin, para la

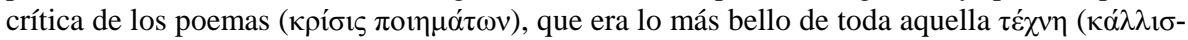

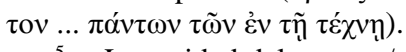

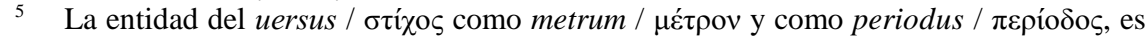
decir, como unidad, respectivamente, de medida y de articulación del lenguaje versificado; de ambos aspectos me ocupo en Luque, Puntos y comas.

6 Diomedes 494,10 s.: Versus est partium legitima dispositio et pedum culta copulatio consonandi specie metricam exhibens regulam.

EMERITA (EM) LXXIII 2, julio-diciembre $2005 \quad$ pp. 303-351 ISSN 0013-6662 
esencialmente filológico, ligado a la práctica de la escritura, al acto de poner por escrito, dentro de los límites materiales de una hoja de papiro o de pergamino o de cualquier otro soporte, las antiguas formas poético-musicales.

$\Sigma \tau i ́ x o \varsigma$, en efecto, remonta a la raíz indoeuropea *steigh-, *stoigh-, *stigh-, cuyo significado básico es el de 'caminar', 'avanzar', 'subir' ${ }^{7}$ (cf. $\sigma \tau \varepsilon i ́ \chi \omega=$

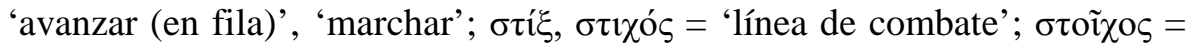

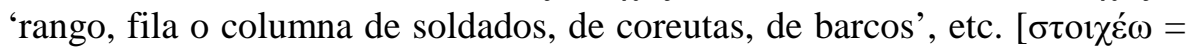

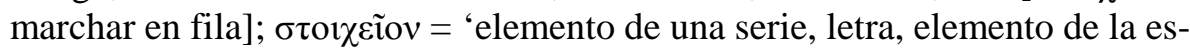
critura, elemento en general' ${ }^{8}$ ). De ahí su sentido de "fila", "línea" (de soldados), "hilera" de árboles; de donde el otro de "línea" o "renglón" de escritura, y luego, el de "verso"; o quizá al revés: primero "línea del texto versificado", es decir, "verso", y, a partir de ahí, línea de la prosa, de un tamaño aproximado al de un hexámetro, o sea, de unas quince o dieciséis sílabas, usada como medida para calcular la extensión de un pasaje u obra ${ }^{9}$.

$\Sigma \tau i ́ \chi o \varsigma$, por tanto, consagrado como tecnicismo en la métrica filológica helenística, no responde a una entidad rítmica y casi tampoco a una métrica; parece apuntar ${ }^{10}$ más bien a una unidad eminentemente gráfica: $\sigma \tau$ í́o $\varsigma_{\text {en }}$ este sentido sería lo que, según el ancho normal de la página, cabe en una línea de dicha escritura.

Ahora bien, aunque es innegable la posibilidad de que el soporte material de la escritura haya influido sobre la propia escritura, hay que reconocer que no lo es todo. En efecto, este hecho de la realización escrita del verso, que, lógicamente, entronca con el otro más general de la escritura del lenguaje, encierra una cuestión de auténtica entidad lingüística. Se trata de trasponer a un código visual unas entidades esencialmente acústicas y dicha visualización, en consecuencia, no es ajena a la propia estructura acústica de aquellas entidades. Por tanto, no hay que olvidar que esa realización escrita del verso, ya desde sus pasos iniciales en las mesas de trabajo de los primeros filólogos, no pudo ser ajena a la articulación oral, acústica, de dichos versos, sino que, al contrario, debió tratar de visualizarla en la medida de lo posible.

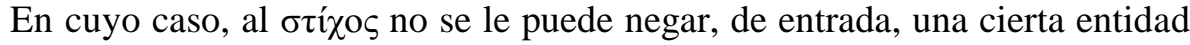

7 Cf., por ejemplo, Pokorny 1969, p. 1017; Frisk 1960 s.v. $\sigma \tau \varepsilon i ́ \chi \omega$.

Sobre el problema de la determinación del sentido originario de $\sigma \tau i ́ \chi o \varsigma$, cf. Desbordes, p. 112 y la bibliografía allí citada.

9 Cf. Liddell-Scott, s.v.

10 Así lo entendía Consbruch (1890, p. 69), quien, en este sentido, remitía a una expresión como $\tau \dot{\alpha} \sigma \tau \imath \chi \eta \delta$ òv $\gamma \varepsilon \gamma \rho \alpha \mu \mu \varepsilon ́ v \alpha$ en los schol. in Dion. Thrac. p. 784,4 y a Studemund, Anecd. Varia, p. 230,17.

EMERITA (EM) LXXIII 2, julio-diciembre $2005 \quad$ pp. 303-351 ISSN 0013-6662 
métrica, aunque sea sui generis ${ }^{11}$.

Interesa dejar bien claro que cuando hablamos de "líneas" nos referimos a "líneas espaciales" ${ }^{12}$, a $\sigma \tau i ́ \chi 01$, que son las que habitualmente se practican en los manuscritos de autores clásicos ${ }^{13}$. Cosa distinta es la escritura por $\kappa \tilde{\imath} \lambda \alpha$ o "líneas de sentido" ${ }^{14}$, propia de la escritura "comática" o "colométrica", que se empieza a difundir más tarde, tanto entre paganos como entre cristianos, en escritos destinados a la declamación en público, bien retórica, bien litúrgica, etc. ${ }^{15}$

Los $\sigma \tau i ́$ oo tenían una longitud media de treinta y seis letras; diecisiete sílabas, es decir, unas treinta y siete o treinta y ocho letras era el tamaño máximo de un verso homérico. Los filólogos alejandrinos podrían haber adoptado esta norma para su biblioteca; y de ahí habría que derivar las características de la escritura "esticométrica" ${ }^{16}$. Bien entendido que naturalmente se

11 Sobre estas y otras cuestiones de la realización escrita del verso, cf. Mariner 1971, pp.

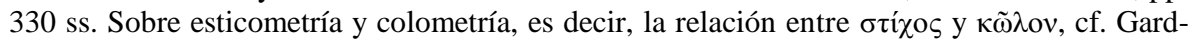
thausen 1913, pp. 70-82. No es ajena a todo esto la escritura comática que desarrollarían, sobre todo, los cristianos, pero que no carece de antecedentes clásicos.

12 "Raumzeilen": Gardthausen 1913, pp. 72 ss.

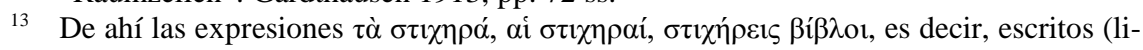
bros, partes, sectores) "dispuestos por versos o líneas".

14 "Sinnzeilen": Gardthausen, lug. cit.

15 Esta escritura "colométrica" constituía, en efecto, un apoyo esencial para el que tenía que leer en la iglesia un largo texto bíblico en uncial sin separación de palabras o de frases. Para facilitar la declamación fueron a veces también organizadas en este tipo de $\kappa \tilde{\omega} \lambda \alpha$ las partes líricas de la tragedia. - No hay, sin embargo, una separación tajante entre otíxor ("líneas

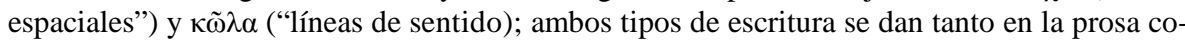
mo en la poesía. Sí es cierto, en cambio, que en los escritos de poesía, retórica, etc. las líneas fueron dispuestas según unos criterios especiales. - Se trata, con todo, de una costrumbre relativamente tardía: en un manuscrito del siglo III, figura un fragmento de la Antíope de Eurípides, con las partes corales sin escritura colométrica; en cambio, en sentido contrario, en el siglo VI el papiro Rylands I 7 presenta un himno escrito por cola y commata: cf. Gardthausend 1913, p. 73.

16 Distinta, como he dicho, de la "colométrica" más propia de la retórica: cf. Graux 1878 y 1893. Se ha distinguido (Diels 1882; cf. también Gardthausen 1913, p. 79.), por un lado, un antiguo $\sigma \tau i ́ \chi 0 \varsigma$ normalizado de quince sílabas en las antiguas ediciones de Heródoto, De-

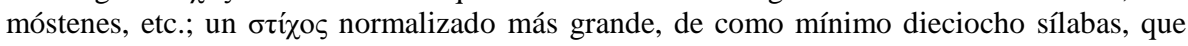

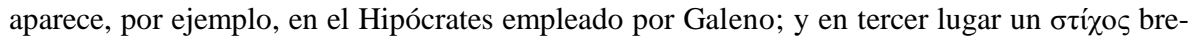
ve que aparece en rollos de Herculano, no empleado como norma o medida. Los romanos (cf. Mommsen 1886, especialmente pp. 146 ss.) habrían simplificado todo esto y tomado como norma, en lugar del verso homérico, las habituales dieciséis (o más exactamente 15,23) sílabas del hexámetro virgiliano (se entienden sílabas escritas, prescindiendo de la elisión o sinalefa que en la pronunciación las reduce con frecuencia a menos).

EMERITA (EM) LXXIII 2, julio-diciembre $2005 \quad$ pp. 303-351 ISSN 0013-6662 
trata de una pauta, no de una regla sin excepciones.

\subsection{El término uersus.}

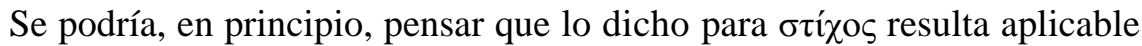
sin más al correspondiente latino uersus, cuya relación con uerto, 'dar la vuelta', es evidente. Tanto Walde-Hofmann ${ }^{17}$, como Ernout-Meillet ${ }^{18}$ definieron uersus como un sustantivo, en principio, abstracto: 'el hecho de dar la vuelta' («das Umwenden», «fait de tourner») ${ }^{19}$ :

si istoc me uersu uiceris, alio me prouocato (Pl. Stich. 770).

hic agit magis ex argumento et uorsus meliores facit (Pl. Trin. 707).

Pero los primeros lo entienden como 'el hecho de dar la vuelta a la tierra con el arado y el surco que de ello resulta'. Los segundos ${ }^{20}$ lo interpretaron como 'el hecho de dar la vuelta al arado, al final del surco'.

En uno y otro caso se hacen derivar de ahí su sentidos concretos: ante todo, el de "surco":

Plin., Nat. XVIII 177: in arando uersum peragi (oportet) nec strigare in actu spiritus;

Colum. Rust. II 2,25: bubulcum oportet alternis uersibus obliquum teneri aratrum et alternis recto ... sulcare ${ }^{21}$;

en este contexto agrícola se habría originado también su uso como medida agraria de longitud e incluso de superficie ${ }^{22}$ :

Varro, Rust. I 10,1: in Campania uersibus (metuntur) ... uersum dicunt centum pedes quoquo uersum quadratum.

A partir de aquí habría adquirido luego el sentido de "línea", "raya", "fila" (por ejemplo, de remeros):

Verg., Aen. V 119: ingentem Chimaeram, \| urbis opus, triplici pubes quam Dardana uersu $\|$ impellunt, terno consurgunt ordine remi;

Liu. XXXIII 30,5: regiam ... inhabilis prope magnitudinis, quam sedecim uersus remorum agebant);

o de "hilera": de árboles:

Verg., Georg. IV 144: ille ... seras in uersum distulit ulmos eduramque pirum;

17 1938, s.v.

18 1967, s.v.

19 Es ésta también la acepción que colocan expresamente como primaria Lewis-Short (Oxford Latin Dictionnary).

20 E indirectamente también Lewis-Short.

21 Lewis-Short reconocen este significado como el originario; los siguientes serían usos en sentido figurado.

22 Cf. Kretschmer 1918, pp. 225 s.; Pokorny 1969, p. 1157.

EMERITA (EM) LXXIII 2, julio-diciembre $2005 \quad$ pp. 303-351 ISSN 0013-6662 
de hojas:

Plin., Nat. XV 122: genera myrti ... Satiuarum genera ... Tarentinam folio minuto, nostratem patulo, hexasticham densissimo, senis foliorum uersibus; o de celdas en una colmena:

Plin., Nat. XI 24: Primi fere tres uersus inanes struuntur, en promptum sit quod inuitet furantem.

Desde aquí habría surgido su sentido figurado de "renglón", "línea" de escritura (ello, sobre todo a partir de una escritura bustrofédica como la de la inscripción del Foro):

Cic., Rab. Post. 14: Glaucia solebat ... populum monere ut, cum lex aliqua recitaretur, primum uersum attenderet;

Cic., Att. II 16,4: deplorat primis uersibus \{sc., de una carta $\}$ mansionem suam;

Nep., Ep. 4,6: uno hoc uolumine uitam excellentium uirorum complurium concludere constituimus, quorum separatim multis milibus versuum complures scriptores ante nos explicarunt;

Hor., Sat. II 5,54: ut limis rapias quid prima secundo \| cera uelit uersu;

Liu. XLI 24,19: quo ... rem ... litteris paucorum uersuum impetraret;

Quint. X 7,11: oculi totos simul in lectione uersus flexusque eorum et transitus intuentur;

Plin., Epist. IV 11,16 Mereor ut uicissim ... perscribas ... Ego non paginas tantum sed uersus syllabisque numerabo. Vale;

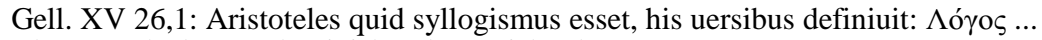

Finalmente habría adquirido el sentido de "verso":

Enn., Sat. 7: Enni poeta salue, qui mortalibus uersus propinas flammeos medullitus; Lucil. 229: festus dies ... quem plane hexametro uersu non dicere possis;

Cic., Brut. 32: primus intellexit etiam in soluta oratione, dum uersum effugeres, modum tamen et numerum quendam oportere seruari;

Cic., Or. 67: quidquid est enim quod sub aurium mensuram aliquam cadit, etiam si abest a uersu - nam id quidem orationis est uitium - numerus uocatur;

Cic., Fam. I 9,23: scripsi ... uersibus tris libros 'de temporibus meis';

Cic., ad Q. fr. II 3,2: cum omnia maledicta, uersus denique obscenissimi in Clodium et Clodiam dicerentur;

Cic., Diu. II 110: Sibyllae uersus obseruamus, quos illa furens fudisse dicitur ${ }^{23}$;

Cat. 6,17: uolo te ac tuos amores $\|$ ad caelum lepido uocare uersu;

Nep., Dion 6,4: uersum illum Homeri rettulit ex secunda rhapsodia;

Hor., Sat. I 10,70: ille (Lucilius) ... in uersu faciendo saepe caput scaberet;

Hor., Epist. II 1,74: si uersus paulo concinnior unus et alter, iniuste totum ... uendit ... poema;

Prop. II 34,93: Cynthia ... uersu laudata Properti;

Phaedr. I pr. 2: uersibus senariis;

Quint. IX 4,71: trimetri uersus pars ultima;

Quint. XI 2,39: facilius uersus ediscimus quam prosam orationem;

23 Cf. asimismo Pis. 72 o Arch. 257.

EMERITA (EM) LXXIII 2, julio-diciembre $2005 \quad$ pp. 303-351 ISSN 0013-6662 
Iuu. 11,182: quid refert tales uersus qua uoce legantur?;

Apul., Apol. 9: uorsus amatorios.

Desde aquí llegó incluso el término uersus a designar a veces "secuencia o patrón melódico", por ejemplo, en el canto de un ave:

Pl., Cas. 523: facito dum merula per uersus quod cantat tu colas;

Plin., Nat. X 106: cantus omnibus (palumbibus) similis atque idem trino conficitur uersu ${ }^{24}$.

Los diccionarios etimológicos de Walde-Hofmann y de Ernout-Meillet, al igual que el de Pokorny, relacionan sin dejar lugar a dudas uersus con uerto; Walde-Hofmann negaban expresamente su relación con uerrere (uersus). A uersus, en efecto, se opone pro(r)sa (oratio), de pros(s)us < prorsus $<$ * pro-uorsus ${ }^{25}$. El sentido primario de prorsus, según Ernout-Meillet, habría sido "qui marche en droite ligne" ${ }^{26}$. De donde el significado de prosa (oratio): "el habla que avanza en línea recta". Prosa, entonces, en cuanto que 'discurso vuelto hacia adelante', se contrapone a uersus, que entraña la vuelta, el retorno cíclico de unidades.

En principio, por tanto, en el caso de uersus nos hallamos ante una etimología transparente, como la de período; etimología de la que parece que había también conciencia ya desde antiguo:

apud nos autem uersus dictus est a uersuris, id est a repetita scriptura ex ea parte in quam desinit. primis enim temporibus, sicut quidam adserunt, sic soliti erant scribere, ut ... (Varro, Serm. lat. 91, p. 220,4 Goetz-Schoell ${ }^{27}$ ).

Prisciano insiste en la misma dirección:

uersus quoque litterarum ordinatio inde dicitur, uel quod uertimus stilum a fine ad initium [vel ab initio ad finem], uel quod antiqui a dextera parte in sinistram et a sinistra in dexteram scribebant (Part. GLK III 514,27).

24 En el Oxford Latin Dictionnary se distribuyen los distintos sentidos del término versus por este orden: 1. Movimiento circular o giro (en una danza) $\|$ 2. Surco, es decir, la tierra vuelta por el paso del arado (De donde, medida agraria). || 3. Hilera o fila (normalmente de cosas concretas). De donde su empleo para designar un banco de remeros. $\| 4$. Línea de escritura. $\| 5$. Verso. De donde su sentido ocasional de segmento melódico.

${ }_{25}$ Cf. Ernout-Meillet, s.v. Para la fonética, cf. dossum, rus(s)um. Prouersus se halla aún atestiguado en Plauto, tal cual, opuesto a transuersus: pseud. 955 Illuc sis uide, ut transuersus, non prouersus cedit, quasi cancer solet. El pasaje lo comenta Varrón, ling. 7,81, en estos términos: apud Plautum '[a]ut trnasversus ... solet'. dicitur ab eo qui in id quod $\langle i>t$ est versus, et ideo qui exit in vestibulum, quod est ante domum, prodire et procedere.

26 De donde el significado de los adverbios prorsus, prorsum = "en línea recta", "todo recto", "adelante", "por completo, "absolutamente".

27 Texto conservado en Aphth.-Mar. Vict. "De uersu", 55,20-56,2, a donde pudo haber llegado a través de Tacomesto.

EMERITA (EM) LXXIII 2, julio-diciembre 2005 pp. 303-351 ISSN 0013-6662 
San Agustín, en cambio, aun cuando participaba de esta idea etimológica de "vuelta", no la refería expresamente a la escritura, sino más bien a la necesidad de límites y cortes impuesta por nuestra percepción ${ }^{28}$. Subyace en ello evidentemente la distinción, tantas veces repetida por él, entre rhythmus, como serie de pies, o sea, secuencia rítmica indefinida, y metrum, como un caso especial de rhythmus en el que dicha secuencia está sometida a modus, es decir, tiene unos límites bien claros. Cuando en esa secuencia rítmica medida se llega al final, se retorna (uerto) de nuevo al principio, se produce una vuelta (uersus). Esos cortes, esas delimitaciones en la secuencia rítmica indefinida vienen impuestas por nuestros hábitos, o incluso necesidades, perceptivas (iudicium). De ahí que afirme:

ne longius pedum cursus prouolueretur quam eius iudicium posset sustinere modum statuit (ratio), unde reuerteretur, et ab eo ipso uersum uocauit ( $O r d$. II 40).

Bien es verdad que de esta manera lo que, según el pensamiento del propio San Agustín, ha quedado definido no es tanto el uersus, sino el metrum, en general. El metrum, en efecto, es un trozo determinado, con un principio y un final, dentro de la serie rítmica, una unidad rítmica que cuando se acaba "vuelve" a empezar. Pero, hablando con propiedad, no todo metrum es un versus; así lo dejará expuesto con toda claridad e insistencia él mismo en su tratado De musica: para que un metrum sea además uersus ha de estar, dice, articulado a base de dos miembros, cuya separación caiga en torno al centro de la unidad. Tan importante es para San Agustín esta nota definitoria del auténtico verso, que llega incluso a modificar la anterior etimología en favor de la idea de que lo esencial en el uersus son esos dos miembros, sucediéndose además en un orden que no sea intercambiable (si se invirtiera ese orden, ya tendríamos otro verso). De ahí viene, concluye San Agustín, el nombre de uersus, por antífrasis, es decir, porque no se le puede dar la vuelta:

Quamobrem non mihi uersus ex eo appellatus uidetur, ut nonnulli putant, quod a certo fine ad eiusdem numeri caput reditur, ut nomen ductum sit ab iis qui se uertunt dum uia redeunt; nam hoc illi cum his etiam metris quae uersus non sunt apparet commune: sed magis fortasse a contrario nomen invenit, ut quemadmodum grammatici deponens uerbum quod litteram non deponit, sicuti est lucror et conqueror, appellauerunt; ita quod duobus membris confit, quorum constituitur in alterius loco salua lege numerorum constituitur, quia uerti non potest, uersus uocatur $\left(\right.$ Mus. V 3,4 $\left.{ }^{29}\right)$.

28 No hay que olvidar que también los rétores reconocían unos condicionamientos cognitivos en la configuración del período como unidad en la que lo conceptual se abre y se cierra, empieza y termina: cf. Lausberg $1960 \S \S 923$ ss.

29 Texto que volvemos a encontrar recogido en Fragm. Parisina, De rhythmo, GLK VI, 631,20 ss.

EMERITA (EM) LXXIII 2, julio-diciembre 2005 pp. 303-351 ISSN 0013-6662 
San Isidoro, hablando precisamente de la escritura y de los factores implicados en su proceso, se adherirá a la idea tradicional de uersus = "vuelta en la escritura", "cambio de renglón":

Versus autem uulgo uocati quia sic scribebant antiqui sicut aratur terra. A sinistra enim ad dexteram primum deducebant stilum, deinde conuertebantur ab inferiore, et rursus ad dexteram uersus; quos et hodieque rustici uersus uocant (Orig. VI 14, De librariis et eorum instrumentis,7).

En cambio, en el libro primero, en un contexto métrico, cuando define el verso, lo hace en los mismos términos de la primera definición de San Agustín, es decir, recogiendo de la etimología la idea de "vuelta", pero sin ponerla en relación con la escritura:

Versus dicti ab eo, quod pedibus in ordine suo dispositi certo fine moderantur per articulos, quae caesa et membra nominantur. Qui ne longius prouolueretur quam iudicium posset sustinere, modum statuit ratio unde reuerteretur; et ab eo ipsum uersum uocatum, quod reuertitur (Orig. I 39, De metris,1).

La misma referencia a la escritura se mantiene, ya en el Renacimiento, por ejemplo, en la conciencia de Escalígero, aun cuando el término uersus no lo relacione ya con uerto, sino con uerro:

Versus primum nomen declarandum est ... De nomine igitur sic: uerrere est idem quod sulcare aut scalpere: tollere aliquid e superficie, ita ut depressio relinquatur. In ceris igitur stilo quum ducerent notas, frequentatiuo usi sunt, sicut et agricolae. Verrunt enim terram, quia quod subtus erat, supra ut sit faciunt. Sic Cicero dicit literas exarare. Ad eum modum uersus dicti sunt lineae illae sulci, quibus uerba scribebantur: quemadmodum in Originibus exactius dictum est. Itaque in omni scriptura tractus singuli orationis uersus sunt appellati. Postea quum redegissent cantum ad numerum castigatiorem, antiquum uersus nomen sibi fecere peculiare. Ex his colligitur definitio: Versus est dispositorum pedum certo numero castigata connexio. Grammatici nugatius: Versus est partium legitima dispositio et pedum culta copulatio consonanti specie metricam exhibens regulam ... (J. C. Escalígero, Poetices libri VII, II,5, p. 58).

En mi opinión, pues, parece estar claro el significado de uersus $=$ "vuelta" y, por tanto, su relación etimológica con verto. Pero precisamente este claro significado etimológico me hace poner en duda la relación de este término con la escritura, tal como habitualmente se reconoce. Versus en este

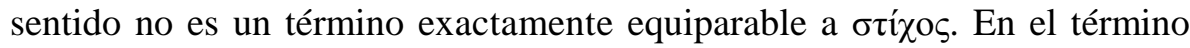
griego su cuna filológica se muestra más clara; su relación con la escritura resulta más evidente; lo cual no anula por completo, como también dije, la posibilidad de que tenga un cierto sentido rítmico-métrico. En el latino uersus, en cambio, este sentido rítmico-métrico puede colocarse en primer plano; lo esencial en él puede ser la idea de "vuelta", de retorno cíclico; ni más 


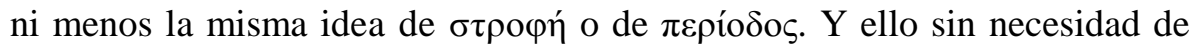
pasar por la escritura: esa "vuelta" puede ser simplemente la que se produce en el proceso rítmico-métrico, el retorno convencional de los factores que van marcando el ritmo y sus unidades. El término, como tal, puede tener, por tanto, unos orígenes auténticamente rítmicos, previos al proceso de escritura de las formas poéticas o musicales, o al margen de dicho proceso ${ }^{30}$.

Este sentido básico de "vuelta" (yo prefiero el de Ernout-Meillet, de "vuelta del arado") es el que fundamenta su posible significado primario de "surco" y los empleos con sentido figurado posiblemente salidos de aquí: entre ellos estaría el de línea de la escritura, tal como se documenta incluso referido a escritura en prosa ${ }^{31}$. Esta "linea de la escritura" puede entenderse, al igual que ocurriría con $\sigma \tau i ́$ ó, como fila de litterae, grammata, elementa, que van avanzando hacia adelante; pero también es susceptible de ser interpretada, tal como hacían los antiguos, como "vuelta", "retorno". Lo cual no haría sino apoyar la posibilidad que estoy sugiriendo.

Con el sentido de "giro, vuelta en el baile", aparece, como hemos visto, uersus en Plauto ${ }^{32}$. Con el sentido de "verso" se documenta ya, como también hemos visto, desde Ennio y Plauto; Cicerón empleó uersiculus y Lucrecio, uersifico.

\section{Las unidades métricas superiores al "verso"}

Hechas estas observaciones sobre el "verso" y su posible sentido grafemático, entremos ya en el ámbito de las unidades rítmico-métricas superiores, en las cuales los tratadistas antiguos reconocían diferentes tipos que de-

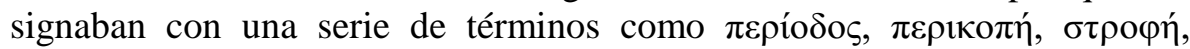

30 En este mismo sentido se manifestó ya Schultz (1885, p. 45, nota 2).

31 Cic., Rab. Post. 14: ut primum uersum (legis) attenderet; Cic. Att. II 16,4: deplorat primis uersibus mansionem suam

32 Stich. 770: si istoc me uorsu uiceris, alio me prouocato: así entendieron el pasaje en sus respectivos diccionarios Gaffiot ("pas de danse") y Lewis-Short ("A kind of dance or a turn, step, pas in a dance") y así lo entienden los traductores: "Si tu m'as battu dans ce pas de danse, j'accepte ton défi pour un autre": A. Ernout, Paris, $1972\left(4^{\mathrm{a}}\right)$; "si me has ganado en este paso de baile, rétame a otro": J.R. Bravo, Madrid, 1995. Yo preferiría traducir "en este giro, en esta vuelta". - Como ejemplo de uersus con el sentido de "vuelta" citaba también Gaffiot Pl. Trin. 707: hic agit magis ex argumento et uorsus meliores facit; los traducores, sin embargo, reconocen aquí el término "verso": "C'est lui qui traite le mieux le sujet et qui fait les meilleurs vers" (Ernout); "El es quien trata mejor el tema y hace mejores versos" (Bravo). A mí, en cambio, no me parece imposible interpretar "éste actúa más de acuerdo con el argumento y da mejor las vueltas".

EMERITA (EM) LXXIII 2, julio-diciembre $2005 \quad$ pp. 303-351 ISSN 0013-6662 
$\sigma v ́ \sigma \tau \eta \mu \alpha$, etc., entre los cuales no resulta siempre fácil clarificar los límites.

La definición, sistematización y estudio de todas estas articulaciones superiores era objeto de una parte específica del sistema de doctrina métrica, la denominada $\pi \varepsilon \rho \grave{~} \pi$ oiń $\mu \alpha \tau o \varsigma$.

\subsection{Los escritos $\pi \varepsilon \rho \grave{i} \pi$ oiń $\mu \alpha \tau o s$.}

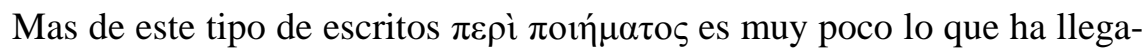
do hasta nosotros: aparte de algunos otros restos menores, las fuentes más importantes son:

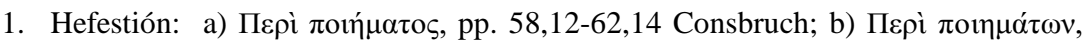
pp. 62,15-73,10 Cons.; Schol. A, pp. 166,8-174,13 Cons.; Schol. B, pp. 262,1263,18 Cons.; Longino, Proleg., pp. 84,5-85,24 Cons.

2. Dionisio de Halicarnaso, comp. verb. XIX pp. $84,15-85,15$; XXV p. 125,8 ss. Usener-Radermacher.

3. Aristides Quintiliano, mus. I 29, p. 52,7-23 Winnington-Ingram.

4. Aftonio/Mario Victorino, $G L K$ VI 56,22-59,29.

5. Diomedes, "De modis metrorum" GLK I 501,29-502,5.

6. San Agustín, mus. IV 17,35; V 13,28.

A ellos se pueden añadir otras informaciones esporádicas procedentes de otra serie de textos, entre los cuales cabe enumerar los siguientes:

1. Las noticias sobre el particular entre los escolios, por ejemplo, a Aristófanes o a Píndaro; en algunos de ellos, sobre todo en los de fecha más temprana, se puede reconocer la huella de métricos como Heliodoro.

2. Isaak Tzetzes AP (Anecdota Graeca Parisiensia, ed. Cramer, Oxonii 1837-41) I $60,12 \mathrm{ss}$.

3. Ioannes Tzetzes AP III 316,28; 317,28.

4. Ioannes Siculus, en Hermogenes, Rhetores Graeci VI 112,24-26;127,13-24; 128,11 ss. 129,7 ss.

5. Cesio Baso GLK VI 266,26-267,2.

6. Terenciano Mauro v. 1801.

7. Sacerdote, $G L K$ VI 517,$4 ; 520,14$.

8. Aftonio / Mario Victorino GLK VI 53,26; 78,19; 104,10 ss. 162,1-3; 170,5; 167,18 .

9. Atilio Fortunaciano $G L K$ VI 282,26; 294,24-27; 295,1-15.

10. Diomedes GLK I 485,18.

\subsection{La doctrina común.}

La penuria de fuentes no permite definir con precisión toda esta doctrina relativa a la articulación de los poemas en su conjunto: a los mencionados problemas conceptuales y terminológicos se suman las dificultades de interpretación de los textos e incluso las discrepancias que en más de una oca-

EMERITA (EM) LXXIII 2, julio-diciembre $2005 \quad$ pp. 303-351 ISSN 0013-6662 
sión se detectan entre unos y otros. En este sentido, sigue siendo básico el trabajo de Consbruch, al editar los textos hefestioneos y estudiarlos dentro del marco de la difusa tradición doctrinal al respecto.

Como líneas generales de toda esta doctrina antigua sobre las diversas posibilidades de organización o articulación del lenguaje versificado, es decir, sobre las distintas maneras de estructurarse las composiciones poéticas, se pueden mantener las que en su día estableció R.Westphal ${ }^{33}$ y recogió después Gleditsch ${ }^{34}$.

\subsubsection{Dos tipos generales.}

La articulación de una composición en verso responde, en principio, a uno de estos dos tipos o modalidades:

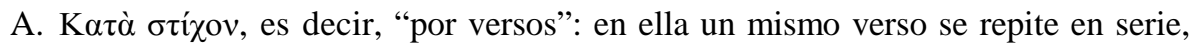
sin que en medio se introduzca ningún otro distinto:

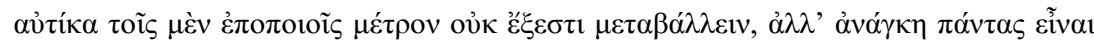

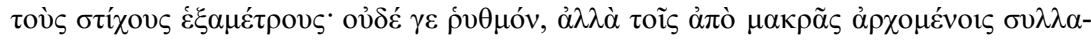

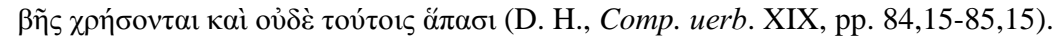

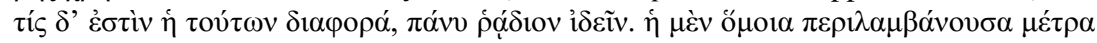

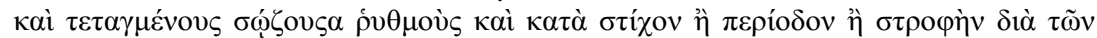

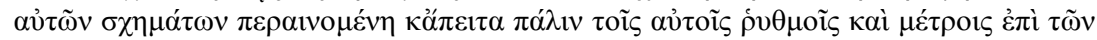

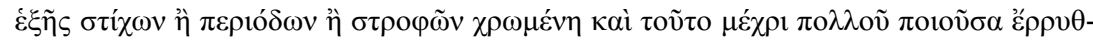

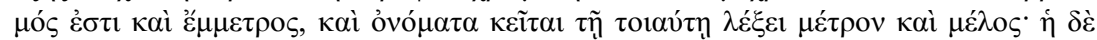

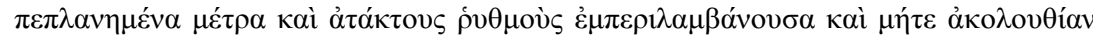

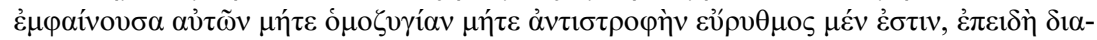

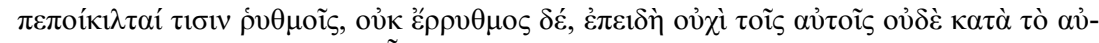

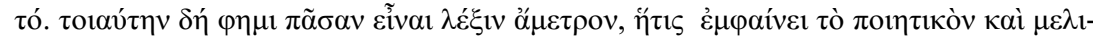

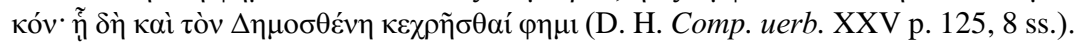

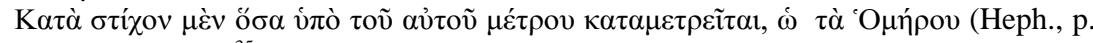
58,17 Consbruch $^{35}$ ).

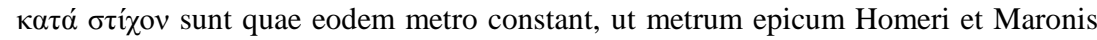
nostri, uel quod ex trimetris et tetrametris continuis subsistit aut colis aut commatibus eiusdem metri (Aphth., 56,24).

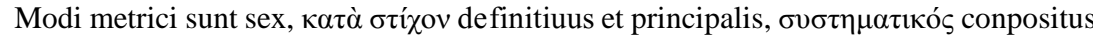
... definitiuus uel principalis est legitimorum metrorum ordo. conpositus constat ex

$331887,1889$.

34 1901. De dichas líneas generales habría que descontar todas las puntualizaciones y precisiones que sobre aspectos concretos, conceptuales y, sobre todo, terminológicos se derivan de estudios específicos como el mencionado de Consbruch; caben asimismo una serie de puntualizaciones sobre unidades articulatorias menores como el colon o el periodos. Pero de todo ello voy a prescindir aquí.

35 Edición por la que lo citaré en adelante.

EMERITA (EM) LXXIII 2, julio-diciembre $2005 \quad$ pp. 303-351 ISSN 0013-6662 
legitimo uersu et eiusdem legitimi medietate isdem pedibus (Diom. p. 501,30 ss.).

Por extensión, como se ve por las anteriores palabras de Aftonio/Mario Victorino, se aplica también esta denominación a las composiciones en las que la serie continua no es de auténticos versos o períodos, sino de cola o commata:

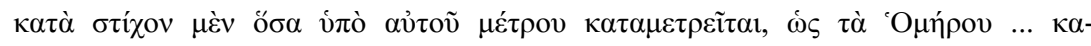

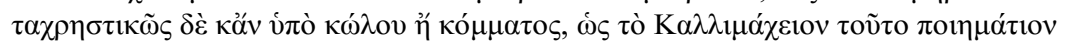
$\dot{\eta} \pi \alpha \tilde{\iota} \zeta \dot{\eta} \kappa \alpha \tau \alpha \dot{\kappa} \lambda \varepsilon \varepsilon \sigma \tau \sigma \varsigma$,

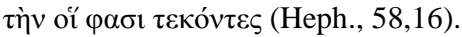

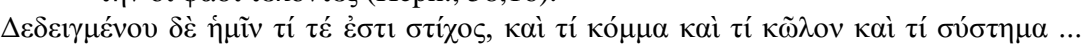

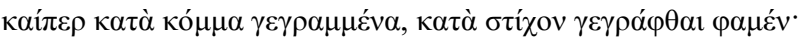

$\dot{\eta} \pi \alpha 1 \zeta \dot{\eta} \kappa \alpha \tau \alpha \dot{\kappa} \lambda \varepsilon \varepsilon 1 \sigma \tau 0 \varsigma$,

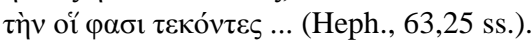

La composición estíquica es propia de la épica y de las partes dialogadas en la poesía dramática. Hefestión, en este sentido, reconocía dentro de los poemas

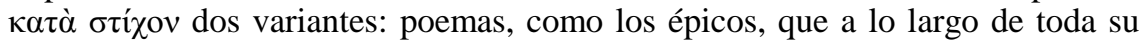

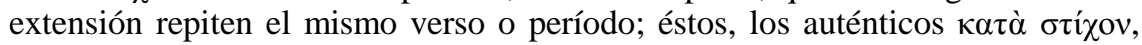

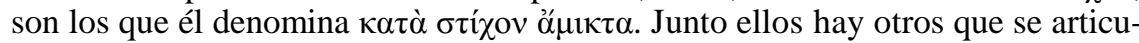

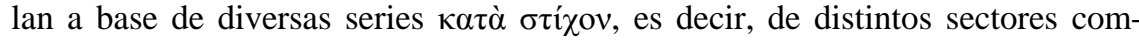

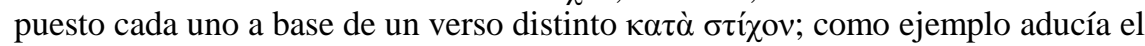
de las comedias de Menandro:

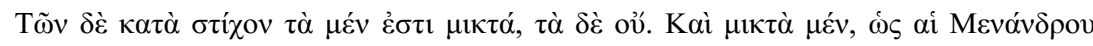

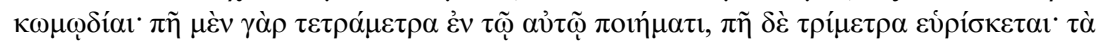

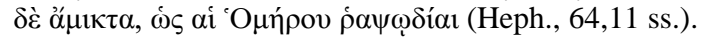

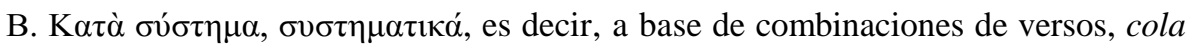
o commata distintos.

Esta composición "sistemática" es la propia de la lírica, en el sentido general y moderno del término, tanto monódica como coral:

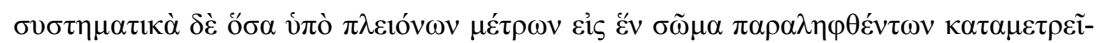

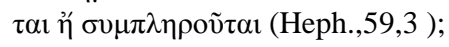

systematica autem, quae ex plurimis metris neque ex uno uersu aut eodem colo uel commate continuentur, ut sunt epodoe et quae apud lyricos inuenimus (Aphth., 57,2 ss.).

C. Es posible la combinación de las dos modalidades en una misma composición, en cuyo caso se habla de un $\pi$ oí $\mu \alpha \mu$ « $\tau$ óv. Es lo que habitualmente ocurre en las composiciones escénicas, las tragedias, las comedias.

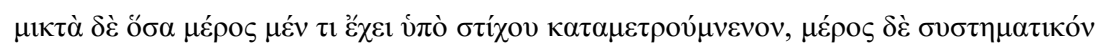
(Heph., 59,5);

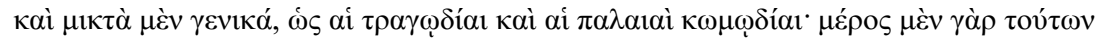

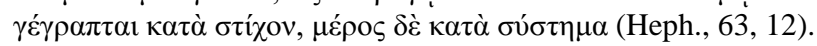

Aftonio, en cambio, parece confundir estos mixta, es decir, las composicio-

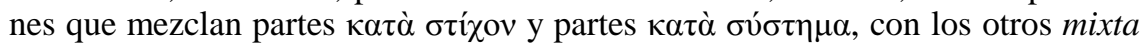

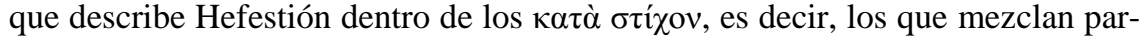

EMERITA (EM) LXXIII 2, julio-diciembre $2005 \quad$ pp. 303-351 ISSN 0013-6662 
tes diversas $\kappa \alpha \tau \grave{\alpha} \sigma \tau i ́ \chi o v:$

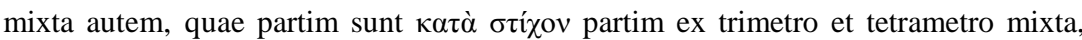
quamquam non [in] uno uersu ... (Aphth. 57,4 ss.).

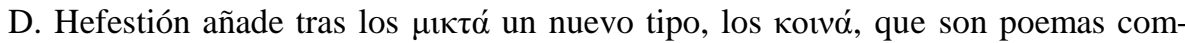
puestos a base de miembros iguales pero que guardan entre sí responsión estró-

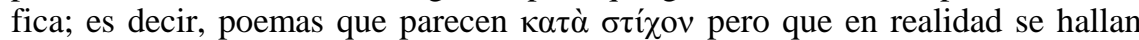

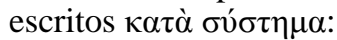

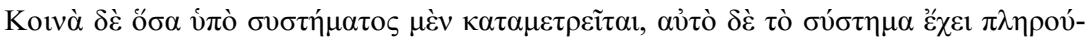

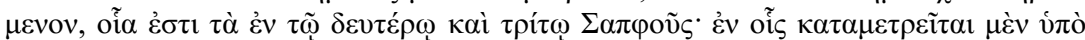

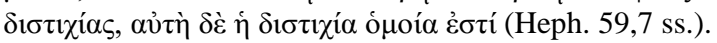

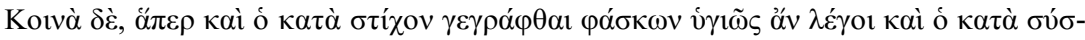

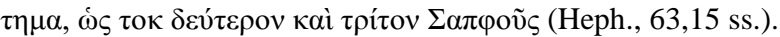

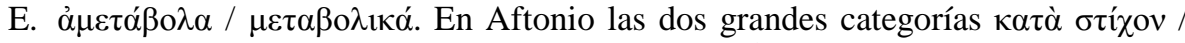

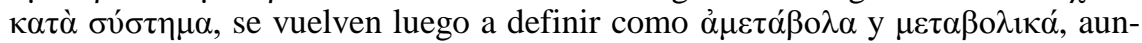
que en esta segunda parecen quedar incluidos también los mixta.

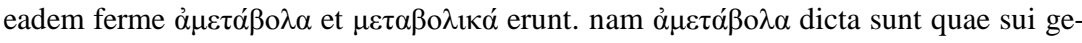
neris qualitatem mensuramque semper obtinent, ut sunt Homeri carmina et ea quae

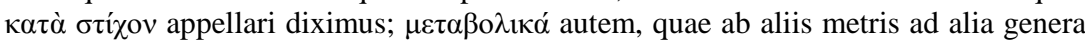
transitum faciunt, qualia esse tragica et comica (Apth. 57,9 ss.).

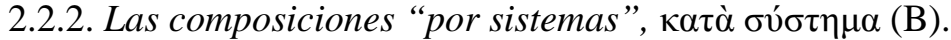

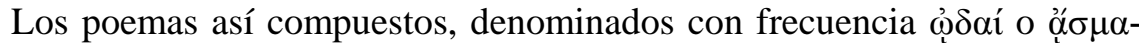
$\tau \alpha$, pueden tener, a su vez, varios tipos de organización, entre ellos dos fundamentales:

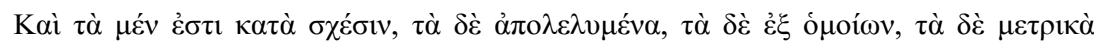

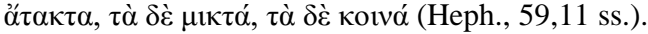

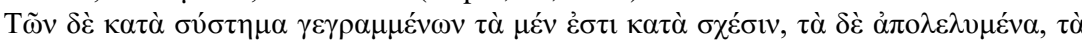

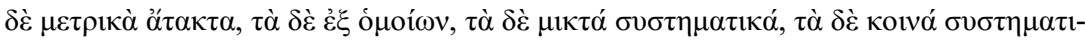
ка́ (Heph., 64,18 ss.).

B. a. A base de repetir cíclicamente la misma combinación ( $\sigma v ́ \sigma \tau \eta \mu \alpha)$; se dice entonces que funcionan "en responsión", $\kappa \alpha \tau \grave{\alpha} \sigma \chi \varepsilon \dot{\varepsilon} \sigma \mathrm{lv}$.

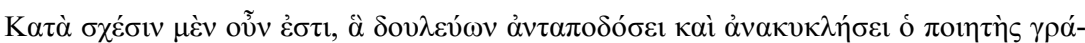
$\varphi \varepsilon \mathrm{(Heph.,} \mathrm{64,22} \mathrm{s.).}$

B. b. A base de que las combinaciones ( $\sigma v \sigma \tau \eta \dot{\mu} \alpha \tau \alpha)$ que se van sucediendo sean distintas. Se trata entonces de "composiciones libres", $\alpha$ $\pi \circ \lambda \varepsilon \lambda v \mu \varepsilon ́ v \alpha$.

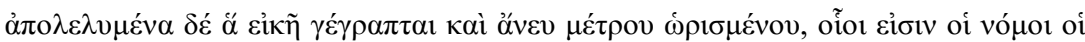

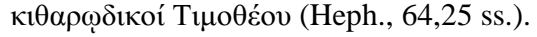

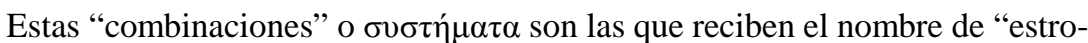

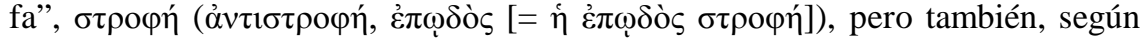


quedó dicho, pueden ser denominadas "período" ( $\pi \varepsilon \rho i ́ o \delta o \varsigma)$ e incluso "metro" 36 ( $\mu \varepsilon \dot{\tau} \rho \circ \mathrm{v}$, metrum), en cuanto que entendidas como unidades métricas superiores.

Los miembros de dichas "estrofas", "períodos" o "metros" son denominados "versos" ( $\sigma \tau$ íxol, uersus) o simplemente $\kappa \tilde{\omega} \lambda \alpha /$ cola, tanto si no constituyen un auténtico verso (por ejemplo, por ser "monocólicos") como si lo constituyen; así se puede dar el caso de que una unidad como el hexámetro dactílico, normalmente considerada como verso/período la encontremos descrita como miembro (colon) de una de estas unidades superiores, una estrofa dística, por ejemplo:

haec ode scripta est ad dicolian, et est primum colon ('diffugere niues redeunt iam gramina campis') epos heroum hexametrum, secundum autem ... penthemimeres, id est hemistichium pentametri, ita, 'arboribusque comae' (Aphth., GLK VI 169,19 ss.).

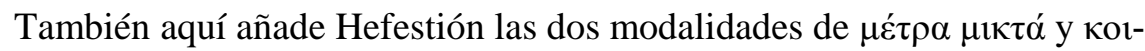
vó:

B. C. Los $\mu 1 \kappa \tau \alpha$ en este caso son los poemas que en parte se hallan organizados "en responsión" y en parte sin ella:

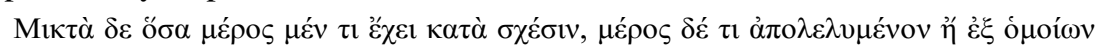
(Heph., 60,9; cf. también 66,5 ss.).

B. d. Los kotvó tienen una estructura que permite considerarlos tanto de un tipo como de otro; parecerían, pues, escritos sin responsión, a base de miembros iguales, pero luego esos miembros están organizados a base de correspondencias

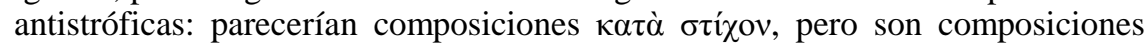
$\kappa \alpha \tau \grave{\alpha} \sigma u ́ \sigma \tau \eta \mu \alpha, \kappa \alpha \tau \grave{\alpha} \sigma \chi \varepsilon ́ \sigma \iota v:$

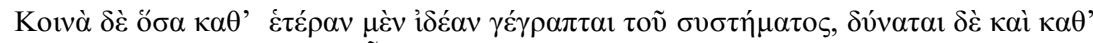

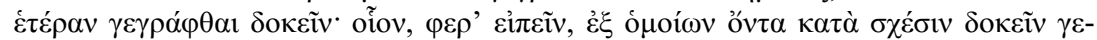
$\gamma \rho \alpha ́ \varphi \theta \alpha \mathrm{l}$ (Heph., 60,11ss.; cf. también 66,10 ss.).

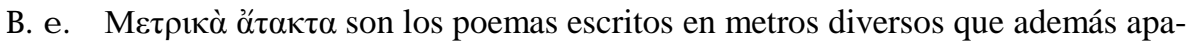
recen mezclados sin orden ni secuencia cíclica alguna:

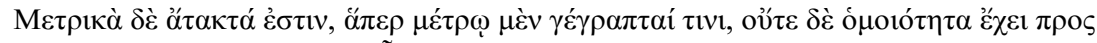

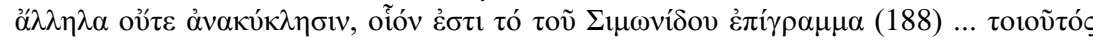

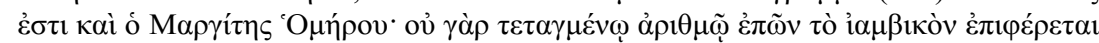
(Heph. 65,3 ss.).

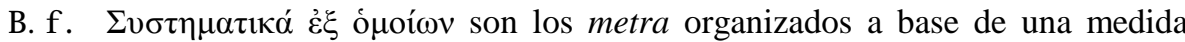
(pie, syzygia, etc.) que se repite indefinidamente; no obstante, luego estas medidas terminan siendo agrupadas en unidades que contienen un número fijo de

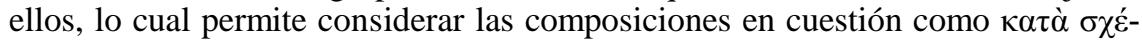
olv. Así aparecen, por ejemplo, los jónicos a minore en Alceo 59 o en Horacio, carm. III 12, donde, aunque escritos, en principio, como una serie indefinida, se agrupan de diez en diez.

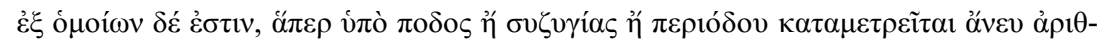

36 Así sucede, por ejemplo, entre los métricos latinos, que tantas veces hablan De metris Horatii.

EMERITA (EM) LXXIII 2, julio-diciembre $2005 \quad$ pp. 303-351 ISSN 0013-6662 


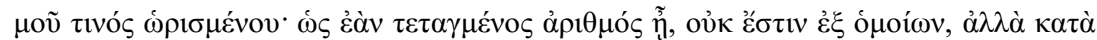

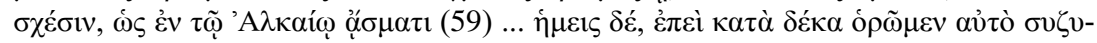

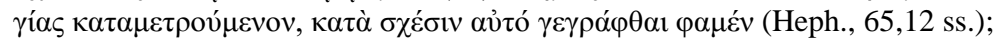

Praeterea et ex se sine ulla pedum admixtione componitur (ionicus) et per se stat integer per synaphian, ut Graeci dicunt, id est cum repetita identidem uice breues longis aut contra breuibus longae subiciuntur ... ut apud Horatium (Carm. III 12) 'miserarum est neque amori dare ludum neque dulci' (Aphth. 91,8 ss.);

cuius (ionici a minore) exemplum apud Horatium reperimus, qui in hoc genere carminis Alcaeum secutus est. et Anacreon lyricus et Euripides tragicus et comici poetae reperti sunt hoc uti numero, cuius exemplum 'miserarum est ...' (Aphth. 129,23 ss.).

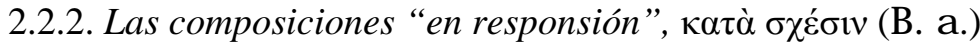

Dentro de las composiciones "en responsión" se pueden distinguir dos tipos:

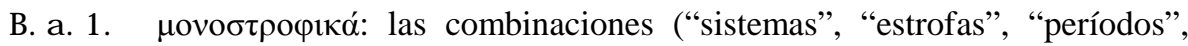
"metros") se repiten siempre iguales a sí mismas; se trata, pues, de una composición "monostrófica": a a' a" a"', etc., del tipo de las que predominan en la antigua lírica monódica griega, tanto eólica (Alceo, Safo) como jónica (Anacreonte), y en las composiciones de los imitadores tardíos tanto griegos como romanos.

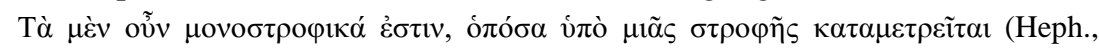
$60,21)$;

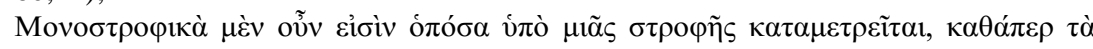

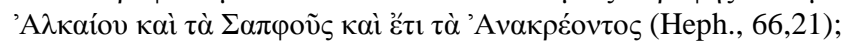

monostropha uocantur haec carmina (SAPH ST), quia ad primam strophen cetera respondent nulla interueniente epodo, quae cum a prima strophe differat, faciat eam, quam musici et grammatici triada nominant. composita autem cola huius carminis singula ex duobus commatibus, quorum ...(Caes. Bass., 266,26-267,2);

quaedam carmina quae monostrophica appellantur, quod duas periodos et eas pares habeant neque epodo, ut alia, concludantur (Aphth., 59,6-7, "De strophe et antistrophe et epodo");

monostropha uocantur haec carmina (SAPH ST), quia ad primam strophen cetera respondent neque ulla interuenit epodos, quae a prima strophe ... discrepet (Aphth. 162,1-3, "De metris Horatianis");

monostropha autem uocantur haec asmata (SAPH ST), quia ad primam strophen cetera respondent (Aphth. 167,18, "De metris Horatianis");

Haec autem Horatii carmina, de quibus dicere institui, monostropha Graeci appellauerunt, quod prima strophe duobus uel tribus uel quattuor colis explicata ceteras sequentes similes habeant, nec in aliqua parte interueniente epodo cola mutentur. colon quid sit iam diximus, a quo dicola siue tricola siue tetracola dicuntur haec carmina (Fortun., GLK VI 294,24-27, "De metris Horatii").

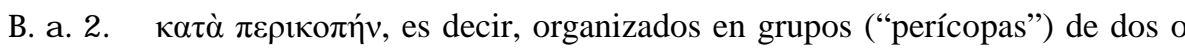
más estrofas o sistemas cada uno: por ejemplo, $\left\langle a a^{\prime} b^{\prime} b^{\prime}\right\rangle, o$ bien $\left\langle a b a^{\prime} b^{\prime}\right\rangle$, etc. Es la estructura típica de la lírica coral, dramática o no; estructura que admite múltiples variantes:

EMERITA (EM) LXXIII 2, julio-diciembre $2005 \quad$ pp. 303-351 ISSN 0013-6662 


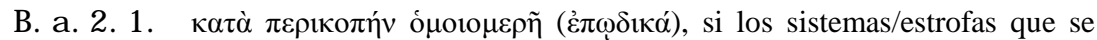
combinan son iguales en todo o en parte: $\left\langle\mathrm{a} \mathrm{a}^{\prime}\right\rangle,\left\langle\mathrm{a} \mathrm{a}^{\prime} \mathrm{b}\right\rangle,\left\langle\mathrm{a} \mathrm{b}^{\prime}\right\rangle$, etc.:

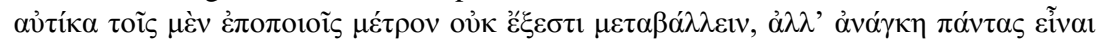

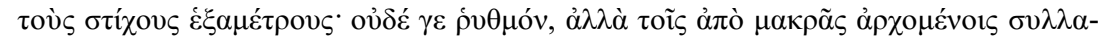

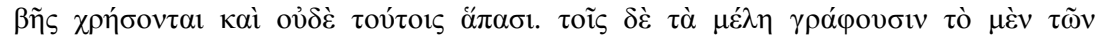

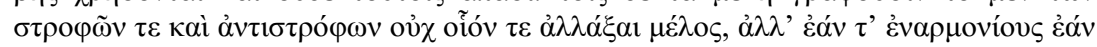

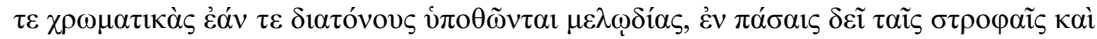

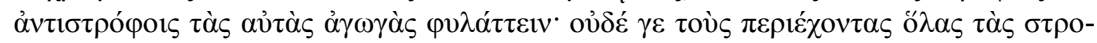

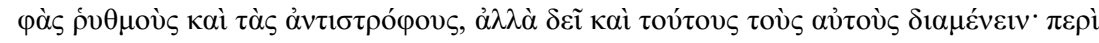

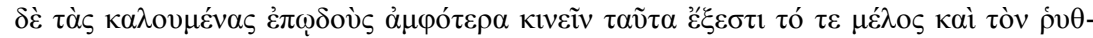

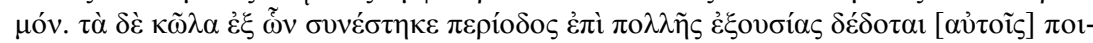

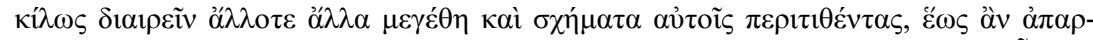

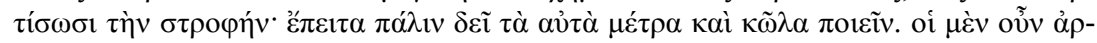

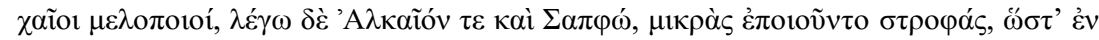

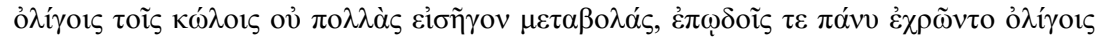
(Dion. Halic, Comp. uerb. XIX, pp. 84,15-85,15).

Se encuadran en este apartado como combinación más relevante las célebres agrupaciones triádicas ( $\tau \rho \alpha_{\alpha} /$ trias) de la lírica coral griega, a base de "estrofa", "antístrofa" y "epodo". Unas tríadas que se van repitiendo a lo largo de la com-

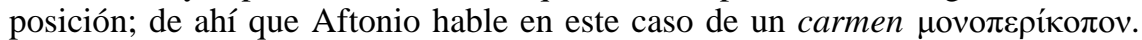

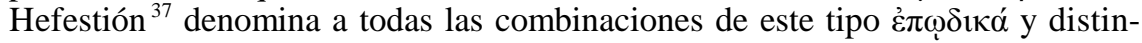
gue dentro de ellas los subtipos que enseguida veremos.

Pleraque lyricorum carminum, quae uersibus colisue et commatibus componuntur, ex strophe et antistrophe et epodo, ut Graeci appellant, ordinata subsistunt, quorum ratio talis est ... hoc quia e tribus subsistit, appellatur $\tau \rho$ ó $\varsigma$ (Aphth. 58,5-23 ${ }^{38}$ );

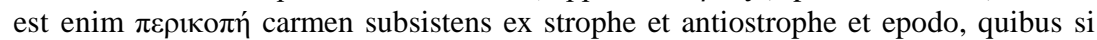

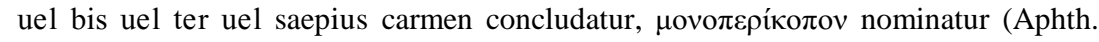
$59,12)$;

in cantionibus autem lyricis legitime scriptis, hoc est monostrophis, haec tria inueniri necesse est, strophen, antistrophen, epodon. olim carmina in deos scripta ex his tribus constabant: circumire aram ... eadem trias, si ex his tribus constat ... haec est ut dixi quam triada appellant (Fortun. GLK VI 294,28, "De metris Horatii" ${ }^{39}$ ).

Tales tríadas, como en general la poesía coral griega, no llegaron nunca a aclimatarse en la versificación latina; de lo cual son conscientes los propios metricólogos romanos, como se puede comprobar por las palabras con las que Ati-

37 61, 1-11; 66,17 ss.

38 Pasa luego a hablar del origen del término a partir de las evoluciones en torno al altar y luego a describir la técnica de la responsión entre los componentes de una tríada y los de las siguientes.

39 Pasa igualmente a describir el origen ritual de estos términos y añade que luego el nombre de epodos se ha trasladado al segundo de los períodos de las denominadas estrofas epódicas: hinc translatum nomen est in has epodos, quae binos uersus impares habent. nam ut illic epodos canticum finit, ita hic uersus secundus sensum: hoc est enim legitimum in epodis. ergo secundum haec et elegia periodos appellatur; eadem trias, si ex his tribus constat.

EMERITA (EM) LXXIII 2, julio-diciembre $2005 \quad$ pp. 303-351 ISSN 0013-6662 
lio Fortunaciano concluye el pasaje: sed quoniam haec accuratius graeci poetae seruauerunt, melius te graeci magistri de exemplis graecis docebunt. nunc ueniamus ad diuisionem metrorum.

Estas tríadas se constituyen a base de dos componentes iguales y un tercero

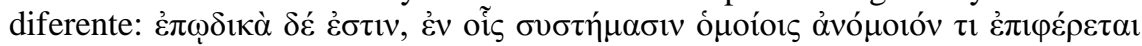
(Heph., 66,24 ss.).

Y según la posición que ocupa dicho componente distinto en el conjunto, reconocen a veces los tratadistas diversos tipos, el primero de los cuales recibe el mismo nombre que el que se otorga a todo el grupo: Toṽ $\delta \dot{\varepsilon} \varepsilon \dot{\pi} \pi \omega \delta 1 \kappa o \tilde{\imath} \gamma \varepsilon ́ v o v \varsigma \tau \grave{\alpha}$

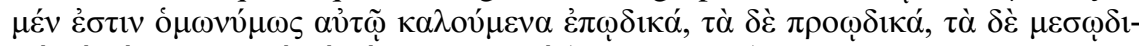

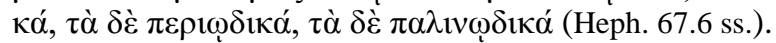

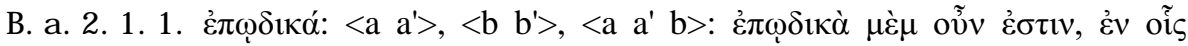

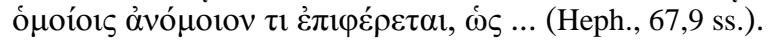

La organización triádica epódica $\langle\mathrm{a}$ a' b> predomina ampliamente en los epinicios de Píndaro. Es también frecuente en el drama, sobre todo, en la "párodos". Otra disposición frecuente es $\langle\mathrm{a}$ a b b (c c ) $\rangle$.

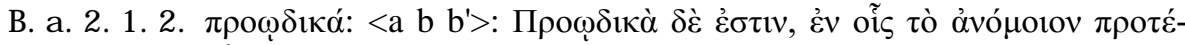
$\tau \alpha \kappa \tau \alpha i \tau \tilde{\omega} v$ ó $\mu$ oí $\omega v$ (Heph., 67,12 ss.).

El sentido de estos términos puede verse claramente explicado en Aftonio / Mario Victorino, aunque allí van referidos no a estrofas ( $\dot{\eta} \dot{\varepsilon} \pi \omega \delta \delta$ ó $\sigma \tau \rho o \varphi \eta ́)$ sino

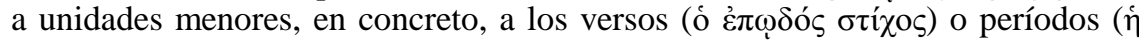

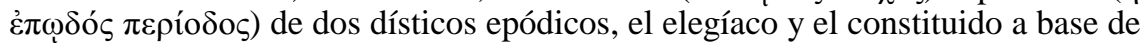
trímetro y dímetro yámbicos:

haec etiam in carminibus, quae mutuo adnexa ita ex se pendent, ut alterum sine altero

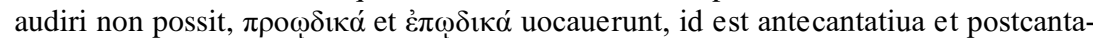

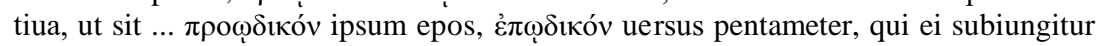
in elegiis. item antecantatiuum erit trimeter iambicus, ut ibis liburnis inter alta nauium;

erit dimeter postcantatiuum, amice propugnacula.

et quaecumque alio quolibet metro scripta sequentes clausulas quorumlibet metrorum

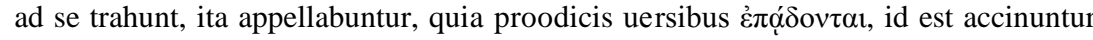
(Aphth. 57,16 ss.).

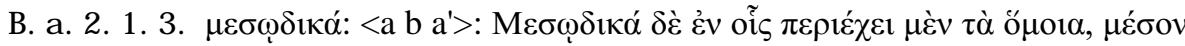

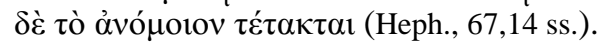

B. a. 2. 1. 4. $\pi \alpha \lambda \iota v \omega \delta \imath \kappa \alpha ́:$ en un conjunto de cuatro se corresponden en una suerte de quiasmo la primera con la cuarta y la segunda con la tercera, es decir, las dos

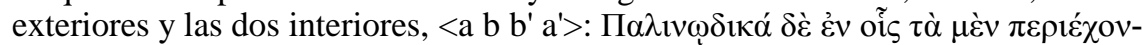

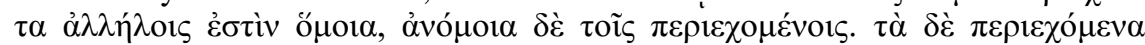

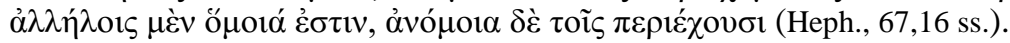

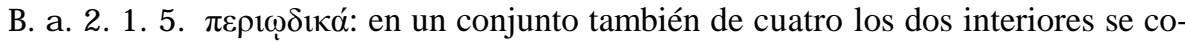
rresponden, pero no así los dos exteriores, que son distintos entre sí y de los in-

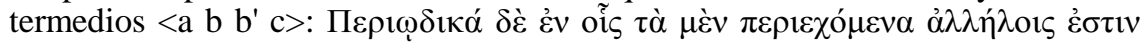

EMERITA (EM) LXXIII 2, julio-diciembre $2005 \quad$ pp. 303-351 ISSN 0013-6662 


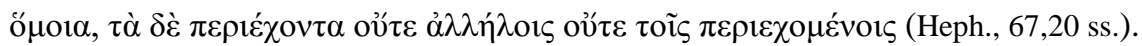

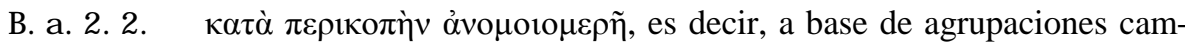

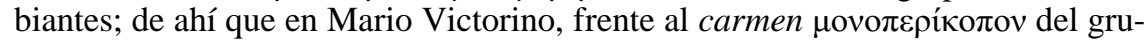

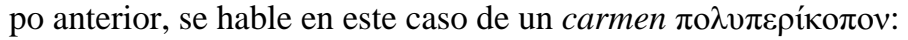

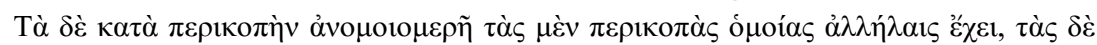

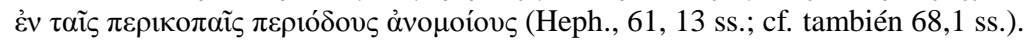

Praeterea reperitur non numquam huius modi compositio uersuum in carminibus, non ut prima compositio secundae compositioni, sicut in $\sigma \tau \rho \varphi \underline{n}$ et antistropho, respondeat, sed ut prima tertiae, secunda quartae similis habeatur, quae compositio $\kappa \alpha \tau \grave{\alpha} \pi \varepsilon-$

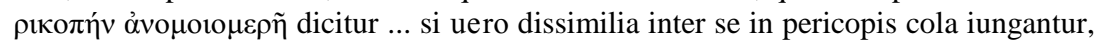
$\pi \mathrm{o} \lambda v \pi \varepsilon \rho$ ќко $\pi$ ov nuncupatur, quando non sollemni continuatione, sed per distantiam et uarietatem in pericopis periodi compleantur, id est tres e quibus pericope subsistit.

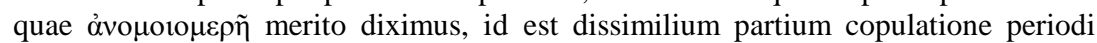
conclusio, siquidem inducta prima strophe et antistrophe rursus aliam strophen et antistrophon praecedentibus dissimilem afferant et rursus tertiam nihil duabus praecedentibus similem et quartam aeque a ceteris cunctis dissimilis aliquando iungatur, quod non tantum tragici sed lyrici auctores in epodis saepe fecerunt (Aphth. 59,8-23).

Este tipo de poemas, según el ritmo de dichas repeticiones, serían, por ejemplo:

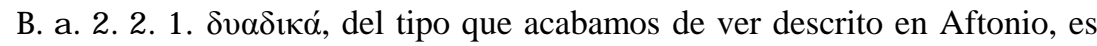
decir, ut prima tertiae, secunda quartae similis habeatur $\left\langle\mathrm{a} \mathrm{b}^{\prime} \mathrm{a}^{\prime} \mathrm{b}^{\prime}\right\rangle$,

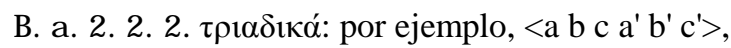

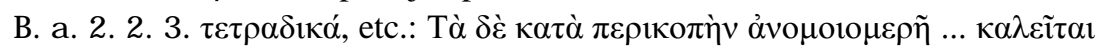

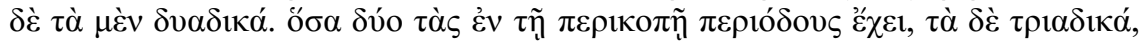

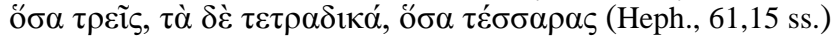

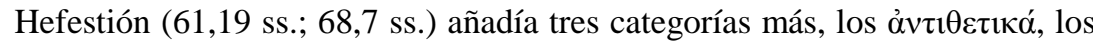

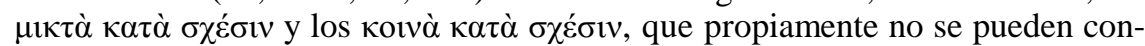
siderar como tales:

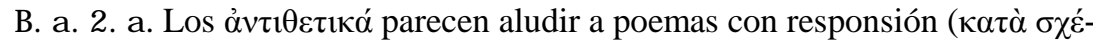
$\sigma \iota v)$, en los que ésta se produce con un especial artificio según el cual el último componente responde al primero, el penúltimo al segundo, etc.:

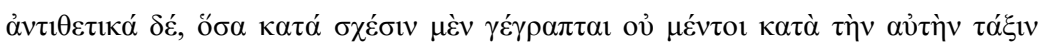

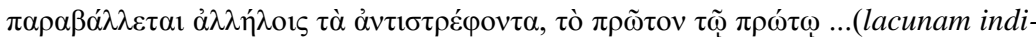

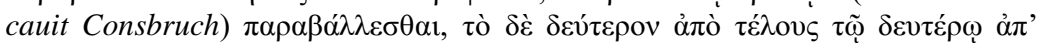

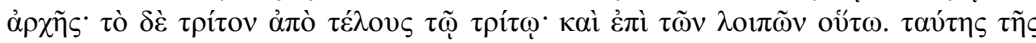

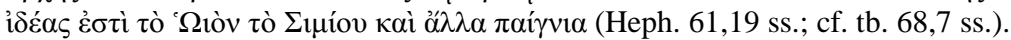

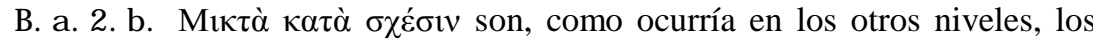

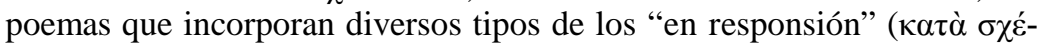
ovv) que se acaban de describir:

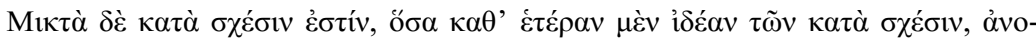

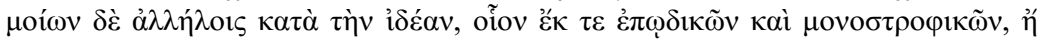

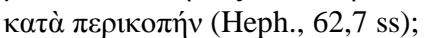

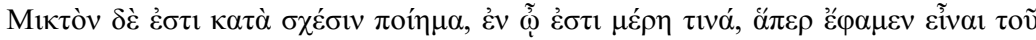

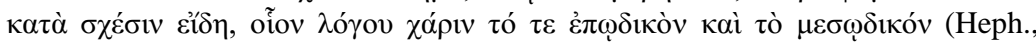

EMERITA (EM) LXXIII 2, julio-diciembre $2005 \quad$ pp. 303-351 ISSN 0013-6662 
68,14 ss.).

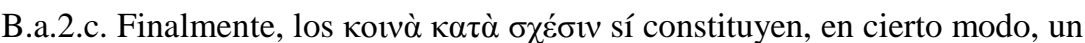
tipo especial de composición: se trataría de poemas que pueden ser interpretados de distintas formas, o sea, que, según se mire, pueden analizarse como escritos según uno u otro de los tipos "en responsión” descritos.

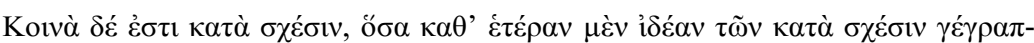

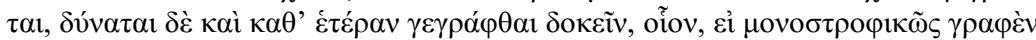

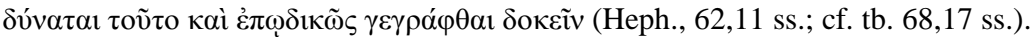

Entrarían aquí, por ejemplo, poemas que constan de estrofas iguales, pero

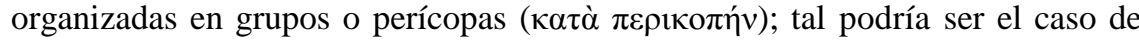
Hor., carm. I 12 cuyas quince estrofas sáficas se pueden entender organizadas en cinco tríadas.

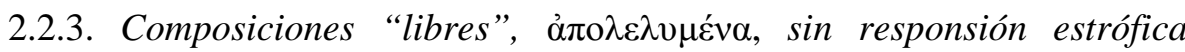 (B.b.).}

Son especialmente cultivadas en los "nómoi" y "ditirambos", sobre todo los de Timoteo y seguidores, y luego en los cantos escénicos del helenismo tardío y de la comedia romana ${ }^{40}$ :

B. b. 1. $\sigma v \sigma \tau \eta \dot{\mu} \mu \alpha \alpha \dot{\varepsilon} \xi$ ó $\mu o i ́ \omega v$ : Composiciones sin responsión, pero de miembros

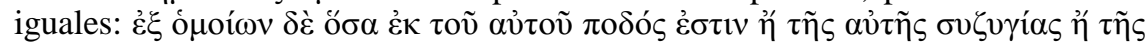

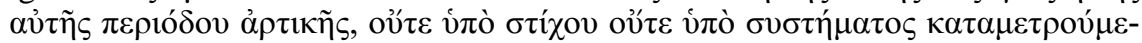

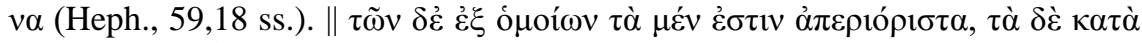
$\pi \varepsilon p ı \rho ı \mu$ ò̀ $\alpha^{\alpha} v i ́ \sigma o v \varsigma$ (Heph., 69,21 ss.).

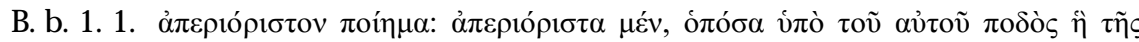

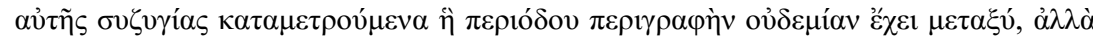

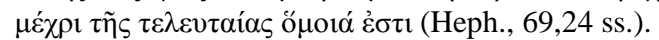

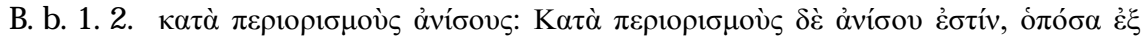

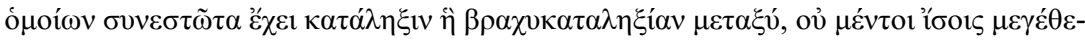

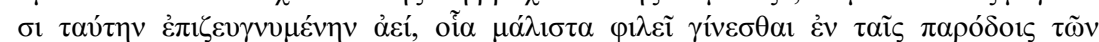

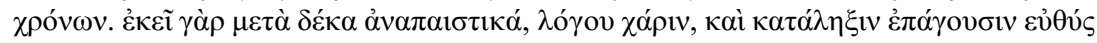

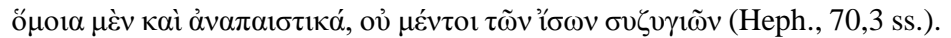

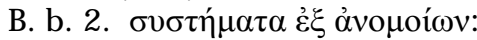

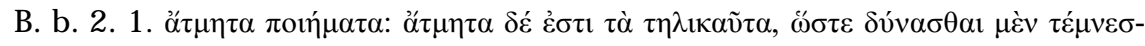

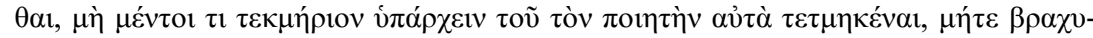

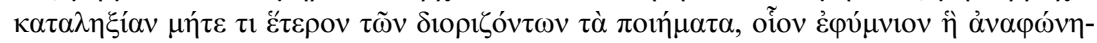
$\mu \alpha$ (Heph., 69,16 ss.).

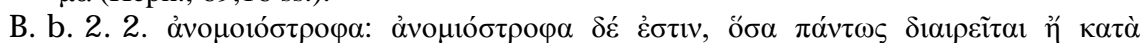
$\pi \rho \sigma_{\sigma \omega \pi \mathrm{ov}} \dot{\alpha} \mu \mathrm{o} \beta \alpha$ ĩov

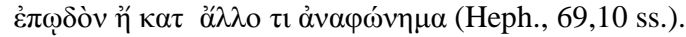

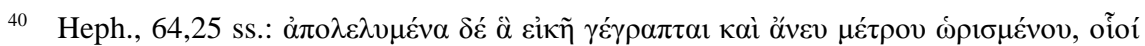

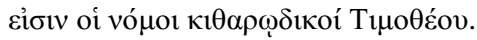

EMERITA (EM) LXXIII 2, julio-diciembre $2005 \quad$ pp. 303-351 ISSN 0013-6662 


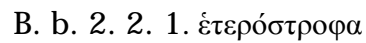

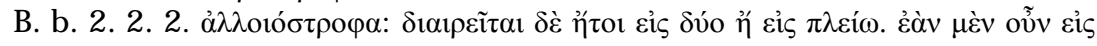

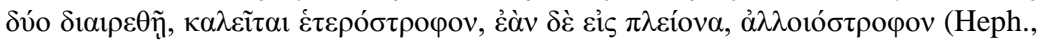
69,13 ss.).

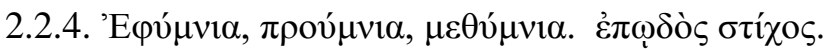

A toda esta descripción de las unidades métricas mayores, se añaden en

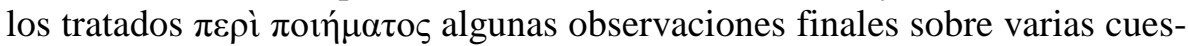
tiones concretas. Dejando lo que Hefestión ${ }^{41}$ presenta acerca de la denominada $\pi \alpha \rho \alpha ́ \beta \alpha \sigma i \varsigma$ de la comedia, me centraré en las otras dos, las relativas a

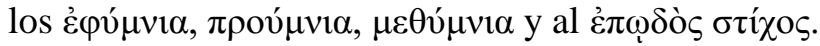

En cuanto a los primeros, se trata de pequeños miembros que pueden aparecer incorporados (después, antes o en medio) a una estructura estrófica (estrofa o antístrofa):

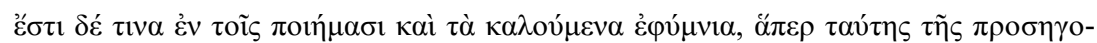

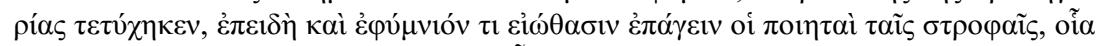

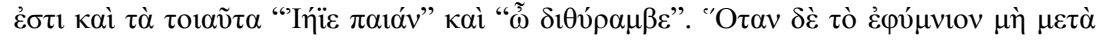

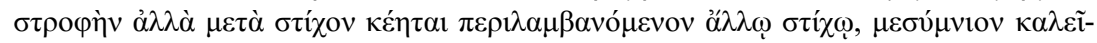
$\tau \alpha 1$... (Heph. p. 70.11).

Hoc loco non supersederim dicere esse breuia cola, quae post strophen et antistro-

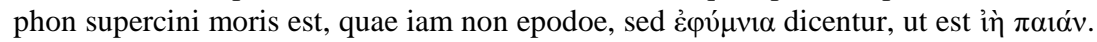
haec enim uel hymnis uel dithyrambis supercini moris est, quae si quando praeponuntur $\pi \rho o v ́ \mu v i \alpha$, si autem post antistrophon collocentur, $\mu \varepsilon \theta v ́ \mu v i \alpha$ nuncupabuntur (Aphth. 59,24).
\end{abstract}

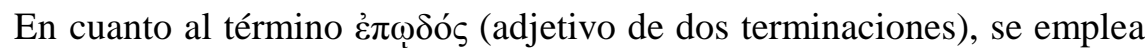

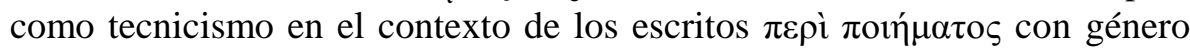
femenino, calificando a $\sigma \tau \rho \circ \varphi \eta \dot{:} \dot{\eta} \dot{\varepsilon} \pi \omega \delta$ ò $\sigma \tau \rho o \varphi \eta ́$. No obstante, como ya ha quedado sugerido más arriba, también puede emplearse, con su mismo sentido de "lo que se canta después", como masculino, aplicado al término otí$\chi 0 \varsigma$ (ó غ̇ $\pi \omega \delta$ ò $\varsigma \sigma \tau \mid \chi 0 \varsigma)$ y referido, por tanto, no a una estrofa, sino a un verso o período dentro de una estrofa, ordinariamente a un verso más corto que sigue a uno más largo anterior; es ésta la estructura de los dísticos típicos de la lírica jonia, constituidos a base de un hexámetro dactílico o un trímetro yámbico seguidos de otro verso más breve, dactílico y/o yambo-trocaico.

De ahí también el nombre de "epodos" con el que se terminaron siendo designados este tipo de dísticos:

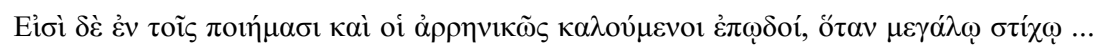

41 Pp. 72,11-73,10.

EMERITA (EM) LXXIII 2, julio-diciembre $2005 \quad$ pp. 303-351 ISSN 0013-6662 


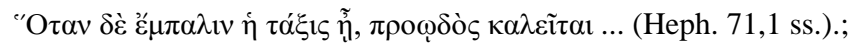

haec etiam in carminibus, quae mutuo adnexa ita ex se pendent, ut alterum sine altero

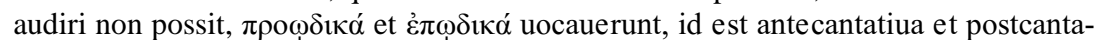

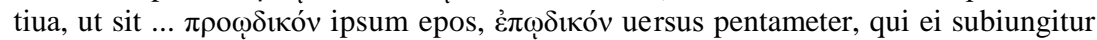
in elegiis. item antecantatiuum erit trimeter iambicus, ut ibis liburnis inter alta nauium;

erit dimeter postcantatiuum, amice propugnacula.

et quaecumque alio quolibet metro scripta sequentes clausulas quorumlibet metrorum ad se trahunt, ita appellabuntur, quia proodicis uersibus غ̇ $\pi_{\alpha} \alpha \delta o v \tau \alpha 1$, id est accinuntur (Aphth. 57,16 ss. ${ }^{42}$ );

epodoe dicuntur uersus quo libet metro scripti et sequentes clausulas habentes particularum, quales sunt epodoe Horatii, in quibus singulis uersibus singulae clausulae adiciuntur ... dicti autem epodoe $\sigma v v \varepsilon \kappa \delta o \chi 1 \kappa \tilde{\omega} \varsigma$ a partibus uersuum quae legitimis et

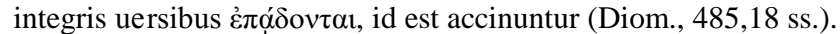

\section{Representación gráfica de este análisis de los poemas.}

Toda esta compleja gama de posibilidades en la articulación de las composiciones en verso tuvo su reflejo en la realización escrita de dichas composiciones; la escritura sintió la necesidad de dar cuenta, dentro de lo posible, de la arquitectura articulatoria de cada poema. Para llevar debidamente a cabo el análisis de la estructura métrica de los poemas y dejar señalizada dicha estructura en las ediciones de los textos, se emplearon una serie de marcas $(\sigma \eta \mu \varepsilon \tilde{\alpha} \alpha)$ que llegaron a constituir un verdadero sistema de signos ${ }^{43}$.

Una de las fuentes gracias a las que conocemos este sistema son precisa-

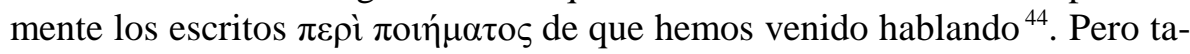
les escritos y los manuales tardíos en que se integran, aunque posibles deudores de los anteriores tratados (y puede que sistemas de notación) de rítmicos y músicos, son sin duda también herederos de una larga tradición grafemática que remonta a las primeras etapas de la actividad filológica alejandrina.

\subsection{Los filólogos alejandrinos y los textos en verso.}

En efecto, la labor de los filolólogos alejandrinos del siglo III a.C., discí-

42 Cf. también 104,10; Ter. Maur. 1801 ss.

43 Enseguida describiremos los más importantes. Bien es verdad que no se trata tampoco de un sistema completamente rígido y que, según iremos viendo, en determinados tipos de composiciones algunos de estos signos pueden tener otro sentido; por ejemplo, el "párrafo" en el drama indica cambio de interlocutor.

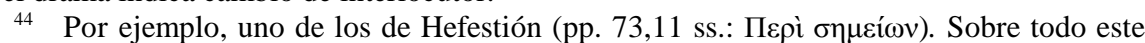
sistema de signos, cf., por ejemplo, Gleditsch 1901, p. 104 s.; Del Grande 1960, p. 288.

EMERITA (EM) LXXIII 2, julio-diciembre $2005 \quad$ pp. 303-351 ISSN 0013-6662 
pulos de poetas y poetas muchos de ellos ${ }^{45}$, se desarrolló ante todo sobre los textos de los antiguos poetas ${ }^{46}$. Centro y objetivo primero de dicha labor fue el texto de Homero; a sus hexámetros, por tanto, estuvieron, en principio, referidas muchas de las marcas que luego se harían habituales en la revisión y preparación crítica de otros textos en verso y que terminarían extendiéndose incluso a los textos en prosa.

Generalmente se asigna a Aristófanes de Bizancio (ca. 257- ca. 180 a.C.) la fijación de este sistema de $\operatorname{signos}^{47}$ (sin que por ello se dejen de reconocer posibles aportaciones previas de sus antecesores, como Zenódoto) para marcar los versos (o las palabras) ${ }^{48}$. Sin duda alguna en la edición del texto homérico se emplearon ya muchos de los signos o marcas que luego conocemos; lo que no se puede determinar con precisión es cuáles de ellos fueron efectivamente empleados por Aristófanes; además del óbelo (“-”), usado ya

45 La serie comienza (cf., por ejemplo, Sandys 1920 pp. 118 ss.) con Filetas de Cos (ca. 340-ca. 285), preceptor de Ptolomeo Filadelfo, de Zenódoto y del poeta elegíaco Hermesianacte. - Zenódoto de Efeso (ca. 325-ca.234), discípulo suyo, fue el primer gran bibliotecario de la Biblioteca de Alejandría, donde se ocupó directamente de la clasificación de los poetas épicos, al tiempo que Alejandro Etolo ( $f l$. 285-276 a.C.: compañero probablemente de Teócrito y de Arato en Cos) hacía otro tanto con los trágicos y con los dramas satíricos y Licofrón (de Calcis, en Eubea, nacido ca. 330/325 a. C.), con los cómicos. Poco antes de 274 publicó la primera edición científica de la Ilíada y la Odisea, basada en numerosos manuscritos, edi-

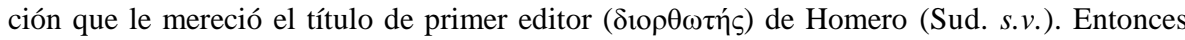
quizá por primera vez se distinguieron en cada obra los 24 libros y se marcaron debidamente con el óbelo los versos espurios. - Calímaco de Cirene (ca. 310-ca.240), en Alejandría desde su juventud, se ha supuesto que sucedió a Zenódoto al frente de la Biblioteca; sea así o no, desarrolló en ella una intensa actividad; a su escuela o círculo pertenecieron los más afamados poetas y filólogos, como su propio rival Apolonio de Rodas, o como Eratóstenes o Aristófanes de Bizancio. - Eratóstenes (ca. 275- ca. 195) fue reclamado desde Atenas para ocupar el puesto de bibliotecario, en el que permaneció durante los reinados de Ptolomeo Euergetes $(\dagger$ 222 a. C.) y Ptolomeo Filopator (222-205). Siguiendo la huella de Calímaco impulsó una actitud de respeto y reverencia ante la figura y el texto de Homero, que luego propiciaría el rigor de filólogos posteriores como Aristófanes o Aristarco. Además de otros muchos trabajos sobre geografía, matemáticas, astronomía y cronología, su principal labor filológica se centró sobre la antigua comedia ática, campo en el que corrigió a sus precedesores, Licofrón o Calímaco. - Su sucesor al frente de la biblioteca fue Aristófanes de Bizancio.

46 Se ha supuesto, al parecer (Pfeiffer 1968, pp. 352 s.) sin fundamento suficiente, que Aristófanes de Bizancio hizo también una edición de Platón..

47 Así como también del sistema de signos prosódicos para indicar los acentos agudo, grave y circunflejo, las cantidades de las sílabas largas (-) o breves ( $)$ ), la división (

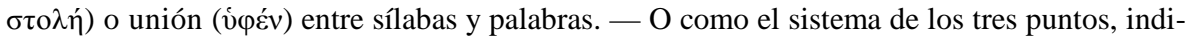

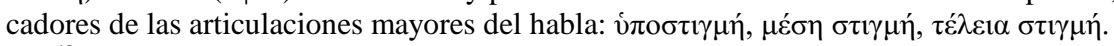

48 Cf. al respecto, por ejemplo, Pfeiffer 1968, pp. 211 ss., 321 ss. y las indicaciones bibliográficas que allí se hacen.

EMERITA (EM) LXXIII 2, julio-diciembre $2005 \quad$ pp. 303-351 ISSN 0013-6662 
por Zenódoto, se habla de que Aristófanes recurrió al asterisco, aunque con un sentido distinto del que luego le dio Aristarco, al "keraunion" (*) y a la "sigma" (C) y la "antisigma" ( $\supset$ ), con el sentido con que luego Aristarco emplearía la "antisigma" y la "stigmé" (.).

Aristarco de Samotracia (ca. 220-145 a.C.) fue discípulo de Aristófanes y le sucedió al frente de la Biblioteca. Sobre la base de las ediciones previas de Zenódoto, de Aristófanes, de Rhianos ${ }^{49}$ y usando además una considera-

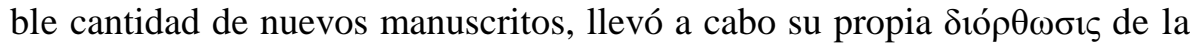
Ilíada y de la Odisea; en el texto de Homero así establecido parece que estaba ya desarrollado el núcleo central de signos críticos marginales que luego habían de quedar como canónicos.

De los trabajos de Aristarco sobre el texto homérico sabemos, sobre todo, a través de los escritos de Aristónico, gramático alejandrino de época de Augusto y Tiberio, y de Dídimo, filólogo alejandrino de la segunda mitad del siglo I a.C. Aristónico ${ }^{50}$, además de autor de comentarios y otros escritos gramaticales, lo fue de un tratado acerca de los signos aplicados al texto homéri-

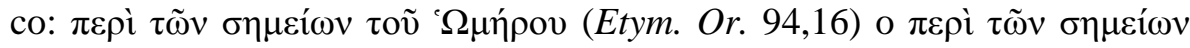

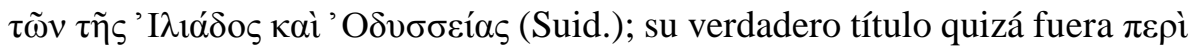
$\tau \tilde{\omega} v$ 'A debió de servirse Aristónico de los comentarios y escritos especializados del propio Aristarco, así como de los escritos homéricos de sus discípulos y sucesores. Los escritos de Aristónico los conocemos a través de los escolios a Homero: los del codex Venetus A, por ejemplo, han transmitido fragmentos suyos, así como otros del $\pi \varepsilon \rho \grave{~ ' A \rho ı \sigma \tau \alpha \rho \chi \varepsilon i ́ o v ~ \delta i o \rho \theta \omega ́ \sigma \varepsilon \omega \varsigma ~ d e ~ D i ́ d i m o, ~ d e ~ l a ~}$

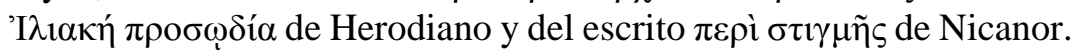

Así, pues, las marcas que describían en sus escritos autores como Aristónico o Dídimo y que luego se han perpetuado en los escolios o en otro tipo de escritos posteriores, remontan casi todas a Aristarco; las demás serían puntualizaciones o correcciones introducidas por sus discípulos ${ }^{51}$ siguiendo

49 Poeta épico y filólogo, originario de Creta, ca. 300 a. C., cf. W. Aly, RE IA, 1920, col. 788 s.; Pfeiffer 1968, p. 224.

50 Cf. L. Cohn, RE II,I, 1895, cols. 964 ss.

51 Entre sus discípulos se cuentan nombres tan significativos como Ammonio, Apolodoro, Dionisio Tracio o Ptolomeo de Ascalona. - Estudio básico de su labor en torno al texto homérico fue en su día el de K. Lehrs (1833). Aristarco llevó a cabo dos ediciones de Homero y se pueden apreciar aún discordancias en las lecturas o en su interpretación de determinados pasajes; todo lo cual puede proceder también de otros escritos especializados o comentarios posteriores, sin descartar la posibilidad, altamente probable, de que el texto original de Aris-

EMERITA (EM) LXXIII 2, julio-diciembre $2005 \quad$ pp. 303-351 ISSN 0013-6662 
el espíritu del maestro, ya que su escuela se mantuvo viva en Alejandría hasta época imperial romana.

\subsection{Las marcas.}

La figura y el significado de los signos críticos con que marcó Aristarco el texto homerico en los márgenes nos son sólo parcialmente $\operatorname{conocidos}^{52}$. El sistema, en sus elementos fundamentales, es el siguiente:

tarco hubiese sufrido alteraciones ante de llegar a manos de Aristónico o de Dídimo. Es más, las obras de éstos últimos quizá tuvieran una de sus razones de ser en el mal estado de los textos de Aristarco o en la deficiente interpretación de los mismos ya por entonces. - Sobre todo ello, así como sobre la gran autoridad de Aristarco aún en época tardía, atestiguada por los escolios a Homero, y sobre las diversas noticias acerca de su vasta producción crítico-filológica, cf. $R E$ II,I, 1895 , s.v.

${ }_{52}$ Las fuentes principales son éstas: Texto y escolios del codex Venetus A (cf. La Roche 1862; C. Wachsmuth, Rhein. Mus. XVIII 178 ss.); es la fuente más importante. — Anecdotum Romanum ed. Fr. Ossan, Giessen 1851: se enumeran y describen los siguientes signos: Tà

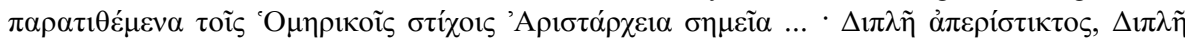

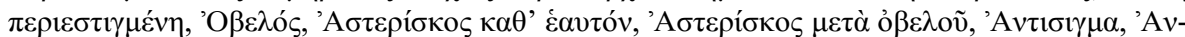

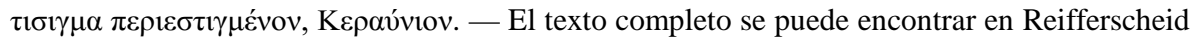
1860, pp. 141 ss. y en Gardthausen 1913, p. 410. - Anecdotum Venetum (lo incluye Reif-

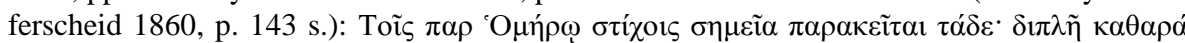

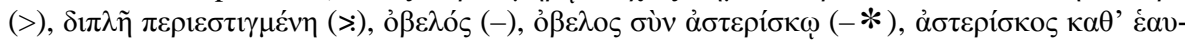

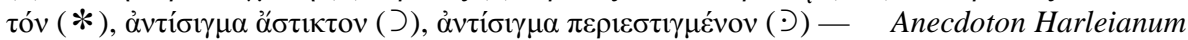

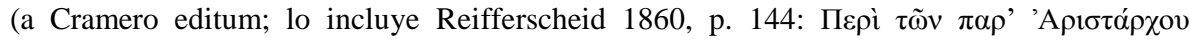

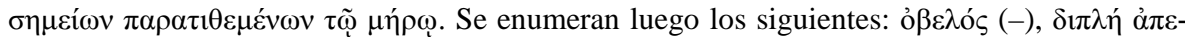

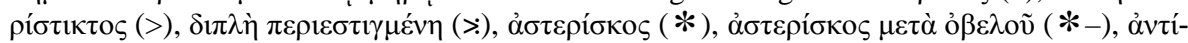

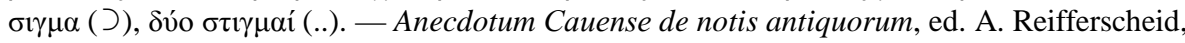
Rhein. Mus. 23, 127 s. (lo recoge Gardthausen 1913, p. 414). Se trata de signos con un sentido estético-retórico: Lemniscus $(\div)$ in acutis. * Asteriscus in sententiis. Oreon cum palma in inuicibilibus acutis. $\Theta$ Theta in amputandis. Oreon in inuicibilibus. - Obelus in translatis. Asteriscus cum palma in sententia acuta. Z Zeta in incertis. Astragalus in elocutis. V Yfen in exemplis. K Kappa in capitibus sensuum. - Reifferscheid 1860, pp. 135-144: a) fragm. 106, pp. 135,19-136,9 (= Isid., Orig. I 21 "De notis uulgaribus. Vulgares notas ... appellantur"); b) fragm. 107, pp. 136,10-137,8 (= Isid. Orig. I 24 "De notis litterarum. Notas etiam litterarum ... scribebant"; c) fragm. 108, pp. 137,9-141,16 (Anecdotum Parisinum e cod. Parisino 7530 a. 780 exarato a Th Mommseno descriptum, deinde a Th Berkio publici iuris factum in Zeitschrift für Altertumsw. 1845, p. 85 sqq. Suetonio idem Berkius uindicauit: "Notae XXI quae uersibus apponi consuerunt ... metaphrasis graeca et latina" GLK VII 533,1-536,23; cf. Isid., Orig. I 20). — Gardthausen 1913, pp. 410 ss. se refiere además a: Diógenes Laercio

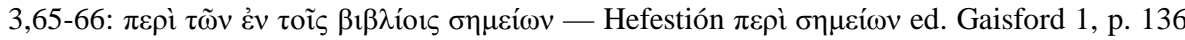
(= p. 73,11 Consbruch): que sólo habla de los signos métricos, no de los críticos de Aristarco. - Cf. también Cohn 1895; Gudeman 1922. - Wingo (1972, p. 18) citaba como lista más completa la ofrecida en Büchner 1961 pp. 329 ss.

$$
\text { EMERITA (EM) LXXIII 2, julio-diciembre } 2005 \quad \text { pp. 303-351 ISSN 0013-6662 }
$$




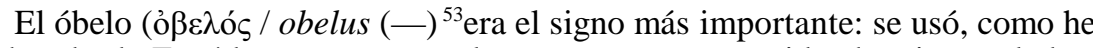
dicho, desde Zenódoto para marcar los versos que se consideraban interpolados, espurios $^{54}$.

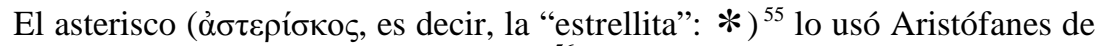
Bizancio para indicar sentido incompleto ${ }^{56}$; Aristarco, para marcar un verso incorrectamente repetido, tomado de otro lugar en el que parecía más apropiado; en caso de repetición de un verso, Aristarco lo marcaba con el asterisco (*) en el lugar en que lo consideraba acertado y con asterisco y óbelo (*-) en el lugar en que era inapropiado. Se empleará luego en los textos de los líricos para indicar cambio de ritmo y también para señalar el final del poema.

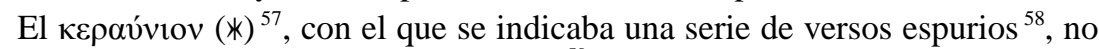
parece seguro que lo empleara Aristófanes ${ }^{59}$.

La $\delta ı \pi \eta \tilde{\eta} \kappa \alpha \theta \alpha \rho \alpha ́$ ("diplé pura y simple": >) ${ }^{60}$ la usó Aristarco para señalar los versos que, a su juicio, presentaban alguna peculiaridad digna de atención:

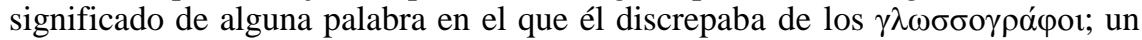

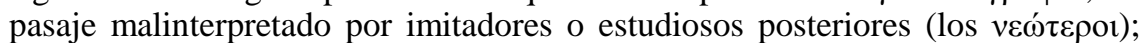
etc. Hay una tradición que, como enseguida veremos, se prolonga hasta la Edad Media latina ${ }^{61}$, según la cual, la diplé la empleó primero un tal Leogoras de Siracusa para distinguir el Olimpo del cielo, pues Homero llama a este último siempre oủpavóv, mientras que con "O $\lambda v \mu \pi$ o se refiere siempre al monte.

Y si Aristarco señalaba con la $\delta \imath \pi \lambda \tilde{\eta}$ sus propias observaciones frente a otras ediciones o explicaciones, marcaba con la $\delta \imath \pi \lambda \tilde{\eta} \pi \varepsilon \rho \imath \varepsilon \sigma \tau \imath \gamma \mu \varepsilon ́ v \eta(>)$ los versos en los que sus lecturas diferían de las propuestas por Zenódoto.

Aristarco parece que usaba la $\delta \imath \pi \lambda \tilde{\eta}$ sola o combinada con puntos $(\pi \varepsilon \rho \imath \varepsilon \sigma \tau \imath \gamma-$ $\mu \varepsilon ́ v \eta)^{62}$ como señal de que la calificación de espurio era sospechosa y también la usó en combinación con la antisigma, de forma distinta a Aristófanes, para indicar un verso que debe seguir inmediatamente al marcado con la antisigma.

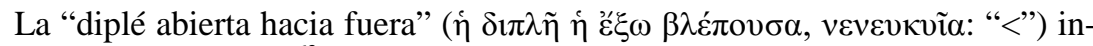

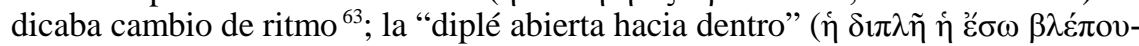

53 Cf. Gudeman 1922, cols. 1920 s.

54 Quintiliano (I 3,3,) lo denomina censoria quaedam virgula. A este signo se ha pensado a veces que remonta nuestra coma.

55 Cf. Gudeman 1922, cols. 1921 ss.

56 Cf. Schol. Od. III 71; Anon. GLK VII p. 534,17 asteriscum Aristophanes apponebat illis locis quibus sensus deesset.

57 Cf. Gudeman 1922, col. 1924.

58 Para otros posibles sentidos, cf. Pfeiffer, ob. cit., p. 322, n. 51

59 Aunque a él se lo asigna en Schol. Od. XVIII 282.

60 Cf. Gudeman 1922, cols. 1918 s.

61 GLK VII 535,7 ss. (Reifferscheid 1860, p. 139); otro tanto en Isidoro, orig. I 21,14,

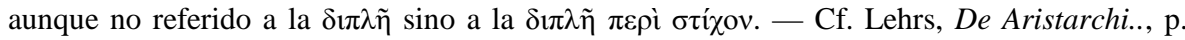
332; H. Usener, Rh. Mus. XX 131, ambos citados en RE II,I col. 866, s.v. Aristarchos.

62 Cf. Gudeman 1922, col. 1920.

63 Cambio que, como enseguida veremos, también se empezó marcando con el asterisco.

EMERITA (EM) LXXIII 2, julio-diciembre $2005 \quad$ pp. 303-351 ISSN 0013-6662 


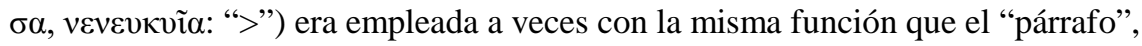
es decir, indicando final de estrofa; la "doble diplé" (" $\geq$ ") marcaba el comienzo de la antistrofa, cuando entre ella y la estrofa había algunos versos intercalados.

La sigma ( $C$ ) y la antisigma $(\supset)$, de las que podrían derivar nuestros signos de paréntesis, se dice que fueron introducidas por Aristófanes para marcar dos versos consecutivos de igual contenido (tautología) y, por tanto, intercambiables ${ }^{64}$. Se dice asimismo que, mientras que Aristófanes usaba la antisigma para indicar repeticiones erróneas, Aristarco parece que la empleó para marcar alteraciones en el orden de palabras. Aristarco, cuando unos versos interrelacionados estaban separados por una interposición sin relación con ellos y parecía necesaria una inversión del orden, colocaba la antisigma ( $\supset$ ) junto al verso al que seguía la interposición y los versos pertenecientes a ella los marcaba con una $\sigma \tau \imath \gamma-$ $\mu \eta ́$ (.); con este simple punto marcaba los versos de cuya autenticidad dudaba, pero que no se atrevía a condenar con el obelo.

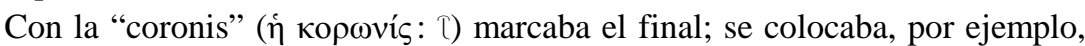
tras el "epodo" para indicar el final de la tríada estrófica.

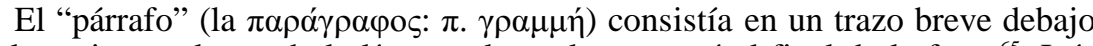
de las primeras letras de la línea en la cual aparecerá el final de la frase ${ }^{65}$. Isó-

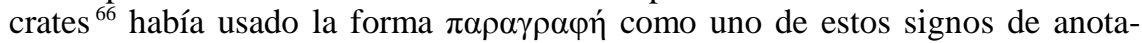
ción. Aristóteles (rhet. 1409 21 ) hace referencia también al empleo de la $\pi \alpha \rho \alpha^{2}-$ $\gamma \rho \alpha \varphi \varsigma^{67}$. Se usó como signo del final de cada estrofa, en cuyo caso era la única marca en el interior de las composiciones monostróficas.

\subsection{Función articulatoria}

Como se ve, no todos estos signos ${ }^{68}$ tienen una función o significado específicamente métrico; unos son ante todo filológicos, otros se diría que tienen un sentido básicamente sintáctico, fraseológico; todos ellos, sin embargo, así como los conceptos o fenómenos que representan, tienen, hasta cierto punto, en común el que, de manera más o menos directa, reflejan en último término aspectos diversos de la articulación rítmico-prosódica del habla. Así lo reconocen de forma más o menos explícita los artígrafos y gramáticos. Así terminará reflejándolo expresamente la tradición gramatical en época tardía y medieval, según veremos más adelante.

\section{La colometría de los versos líricos.}

64 Cf. Schol. Od. V 247 y Schol. Arist., Ran. 152.

65 Pfeiffer 1968, pp. 323 s.

66 Antidosis 15,59.

67 Cf. también Platón, Prot. 345d (=Poetae Melici Graeci 542).

68 Sobre ellos, cf., por ejemplo, Lameere 1960, pp. 190-204.

EMERITA (EM) LXXIII 2, julio-diciembre $2005 \quad$ pp. 303-351 ISSN 0013-6662 
Si la actividad de Aristófanes y demás filólogos fue trascendental para la historia posterior del texto homérico, no lo fue menos para la del hesiódico $^{69}$ y para el de la poesía lírica, incluida la integrada dentro del drama; en este campo se considera la obra de Aristófanes como "un acontecimiento que hizo época" ${ }^{70}$; en efecto, al igual que Zenódoto o Alejandro de Etolia ${ }^{71}$ o Licofrón habían intentado poner orden en los escritos de los épicos, trágicos y cómicos, así Aristófanes se ocupó de la producción de los líricos en conjunto: hasta entonces sólo se les había prestado atención de forma aislada; ahora se los reunió, clasificó y presentó en conjunto con arreglo a unos principios y criterios uniformes ${ }^{72}$.

De particular importancia fue la labor destinada a distinguir y marcar en los textos la estructura rítmico-métrica de dichas composiciones: su organización en estrofas y su articulación en cola ${ }^{73}$. Aristófanes recurrió a un sistema de signos para marcar esta estructura, por ejemplo, los finales de las estrofas o de las antístrofas, o los de cada composición; o los cambios de ritmo ${ }^{74}$. Por supuesto, este análisis métrico, a su vez, daba ocasión para descubrir falsas lecturas o cualquier otro tipo de alteración de los textos.

Así, gracias a la obra de Aristófanes y de sus predecesores ha llegado a nosotros toda esta producción de los antiguos poetas líricos. Bien es verdad que sólo su componente lingüístico y sus formas métricas; no así, en cambio, su componente musical; de dicha música, podemos vislumbrar el factor rítmico a través de los textos conservados; lo melódico, en cambio, quedó irremisiblemente perdido; y ello a pesar de que hasta el siglo IV el $\mu \varepsilon ́ \lambda o \varsigma$ había formado con la $\lambda \varepsilon^{\prime} \xi 1 \zeta$ un todo indisoluble. Es precisamente a partir de entonces cuando se desencadena la disociación de los elementos de la antigua $\mu$ ovбıкń, que irán cobrando autonomía poco a poco, dando lugar a for-

\footnotetext{
69 Que Aristófanes hizo una edición de Hesíodo con marcas críticas semejantes a las empleadas para Homero, se puede ver, por ejemplo, en los escolios a Hesíodo, Theog. 68, donde

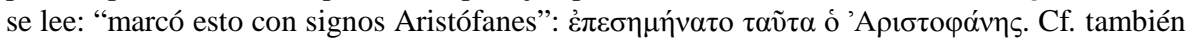
Quint. I 1,15: "en efecto, él (Aristófanes) fue el primero que dijo que Hypothekai, libro en el que se encuentra esto escrito, no era de este poeta (Hesíodo): nam is (Aristophanes) primus

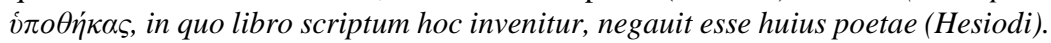

70 Pfeiffer 1968, p. 326.

71 Poeta elegíaco del siglo III a. C., bibliotecario en Alejandría.

72 Por desgracia, en cuanto a su dedicación a este o aquel poeta en particular no estamos en condiciones de entrar en detalles concretos; acerca de su trabajo sobre la obra de Alceo, de Alcmán, de Píndaro, etc., cf., por ejemplo, Cohn 1895, col. 998.

73 Cf., por ejemplo, Dion. Halic. comp. verb. 22 ó 26.

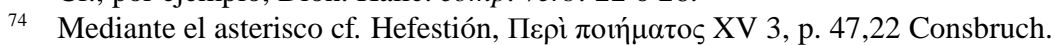

EMERITA (EM) LXXIII 2, julio-diciembre $2005 \quad$ pp. 303-351 ISSN 0013-6662 
mas de expresión hasta entonces desconocidas, como, por un lado, los versos recitados, sin melodía, o, por otro, la música instrumental "sin letra".

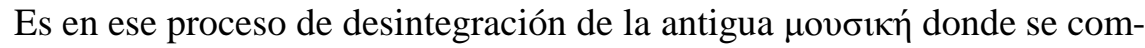
prende la presencia de grupos de sofistas o de filósofos en general que, cuando se ocupan de la poesía antigua, atienden sólo a la lengua ${ }^{75}$; una actitud próxima a la adoptada por los filólogos al editar a Píndaro o a Anacreonte. Dichas ediciones helenísticas dejaron a un lado la posible notación "musical", vocal y/o instrumental, que tal vez acompañaba al texto de las composiciones ${ }^{76}$.

Aunque con notables precedentes en este sentido, como los de Zenódoto o Calímaco o Eratóstenes, el paso decisivo en la edición de esta poesía lírica lo dio Aristófanes. Al lado no sólo de la poesía épica, sino también de la elegíaca y de la yámbica, en las que el componente musical era de menor entidad, lo que se entendía por poesía lírica era la auténticamente cantada, con acompañamiento ante todo de la lira o de otros instrumentos de cuerda similares e incluso también de danza. Es esta poesía la que se considera ver-

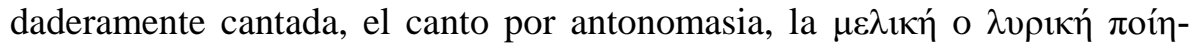

75 Cf. Pfeiffer 1968, p. 326 e indicaciones de la nota 68.

76 Bien es verdad que, como se sabe, los estudiosos no se ponen de acuerdo sobre la fecha en que se crearon y se difundieron dichos sistemas de notación de la melodía vocal y/o instrumental que acompañaba al texto. Nosotros los conocemos sólo por fuentes tardías (cf., por ejemplo, Neubecker 1977, pp. 118 ss.) y, aunque, como digo, las opiniones al respecto varían nada menos que entre los siglos VIII y III a.C., es más bien esta datación tardía la que suele prevalecer : cf., por ejemplo, West 1992, pp. 254 ss. — Es difícilmente imaginable que composiciones líricas tan complejas como las de Píndaro o como las del teatro circularan sin notación ninguna melódica ni rítmica, pero no tenemos noticias solventes que permitan afirmar con seguridad la existencia de dicha notación y menos de un modo sistemático. Este sistema no se documenta consolidado hasta mediados del siglo III a.C. Lo que existió antes queda para nosotros en la oscuridad. Parece que de los dos sistemas de notación alfabética de la melodía el más antiguo, al menos en su núcleo central, es el de la melodía instrumental; el de la notación de la melodía vocálica parece que se puede fechar a finales del siglo $\mathrm{V}$ o comienzos del IV a.C. - La primera notación musical de que tenemos noticia parece apuntar a unos años antes del 450 a.C. y al Noreste del Peloponeso, una región que por esas fechas se reconoce especialmente avanzada en técnicas y teorías musicales. La primera referencia explícita a estos sistemas de notación es la que hace Aristóxeno (nacido ca. 375 a. C.) en los Elementa harmonica (II 39-41), donde aún muestra sus reservas ante el procedimiento. - Por todo ello, cuando vemos a autores como Aristóxeno o como Glauco de Regio (segunda mitad del s. V a.C.) referirse a la música de Olimpo, de Terpandro, de Safo o de Estesícoro, no debemos imaginar que había una tradición de música escrita. Una tradición musical existía, en efecto, pero era esencialmente oral.

EMERITA (EM) LXXIII 2, julio-diciembre 2005 pp. 303-351 ISSN 0013-6662 
$\sigma i \varsigma^{77}$. Es, pues, en esta poesía donde más de lamentar resulta que en la codificación escrita que de ella se hace en esta época no quedara plasmado dicho componente melódico.

El componente rítmico queda recogido en buena medida por la forma métrica, que en lo sucesivo iba a ser el único rasgo formal específico de estos géneros poéticos. En las clasificaciones de dichos géneros o subgéneros iba a intervenir esta forma métrica al igual que otros factores de contenido, una clasificación en la que debió de ser decisiva también la labor de Aristófanes.

Las referencias que tenemos a la edición de los poetas líricos elaborada por Aristófanes son escasas; como ocurrió con el de Homero, su texto fue suplantado por el comentario de Aristarco. Sabemos de algunas observaciones suyas sobre la prosodia, pero no así de las que debió de hacer en el plano de la dialectología o de la ortografía. Ni siquiera se puede determinar cuántos poetas líricos editó. Sí parece, en cambio, seguro que los textos de los líricos que preparó Aristófanes se diferenciaban de todos los de los filólogos anteriores en algo fundamental: se hallaban dispuestos por miembros rítmico-métricos, por $\kappa \tilde{\omega} \lambda \alpha$, no escritos seguidos como si fueran prosa.

Antes de Aristófanes no tenemos noticias fehacientes acerca de la división en cola de los textos de poesía lírica. Sí es un hecho que los poetas de época de Filetas (ca. 300 a. C.) y en especial los del círculo de Calímaco (ca.

77 La primera denominación parece la más antigua y, como se ve, hace referencia a su entidad de poesía cantada: $\mu \varepsilon ́ \lambda o \varsigma$, aunque en principio puede que aludiera a la estructura rítmica de dichas composiciones (pues su significado originario parece que era el de "miembro”, al igual que $\kappa \tilde{\omega} \lambda$ ov: cf. Luque 1999b), pasó pronto a designar la estructura melódica, el

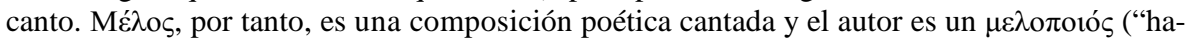

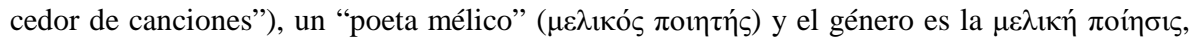
la "poesía cantada". Era ésta la terminología corriente, que luego se mantendrá en las disquisiciones o exposiciones teóricas. En cambio, en las listas de autores o en las referencias a las

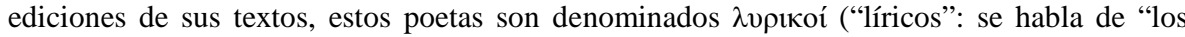

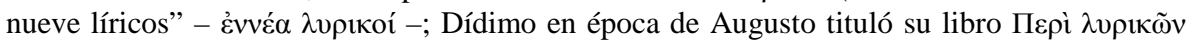
$\pi$ oıฑ $\tilde{\omega} v)$ y a partir del siglo I su poesía comenzó a ser denominada $\lambda$ lírica”, es decir, "poesía cantada al son de la lira”. En latín melicus aparece a veces, por ejemplo, en Cicerón, pero el término corriente será lyricus, que se impone, sobre todo, a partir de época augústea: Horacio, por ejemplo, desea ser contado entre los lyricis (no entre los melicis) vatibus; Ovidio siempre empleará el término lyricus. Y otro tanto harán luego Quintiliano, Plinio o Séneca. Hasta entre los teóricos latinos terminará lyricus imponiéndose sobre melicus, término éste que, al igual que sus derivados, quedará relegado cada vez más al ámbito de la nueva jerga musical. — En todo este proceso de cambio terminológico sugería Pfeiffer (1968, p. 329), de quien he tomado estas notas, la posibilidad de reconocer la influencia de Aristófanes de Bizancio.

EMERITA (EM) LXXIII 2, julio-diciembre $2005 \quad$ pp. 303-351 ISSN 0013-6662 
300-240 a.C.) empleaban en tiradas estíquicas recitadas miembros ( $\kappa \tilde{\omega} \lambda \alpha)$ de antiguas composiciones líricas, lo cual supone una atención especial a dichas articulaciones y sugería a Pfeiffer $^{78}$ la posibilidad de ver en esta práctica versificatoria de los poetas un antecedente de la práctica colométrica que implantará Aristófanes en sus ediciones.

Aristófanes, por ejemplo, tenía conciencia de la repetición en serie de este tipo de unidades articulatorias y marcó sus comienzos con la $\pi \alpha \rho \alpha ́ \gamma \rho \alpha \varphi \circ$.

Las unidades estróficas tampoco quedaron sin marcar ${ }^{79}$. En las composiciones monostróficas, como las de Safo o Alceo o Anacreonte, en las que

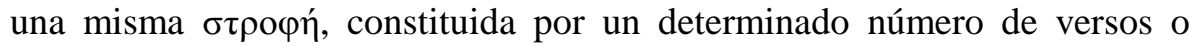
$\kappa \tilde{\omega} \lambda \alpha$, se repetía varias veces a gusto del poeta, se marcaban los límites de estrofa con la $\pi \alpha \rho \alpha ́ \gamma \rho \alpha \varphi$ y $_{\text {y }}$ el final de la última estrofa, es decir, de todo el

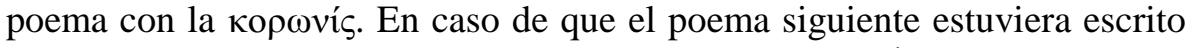

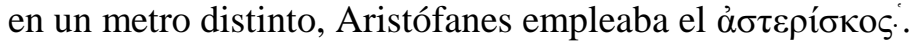

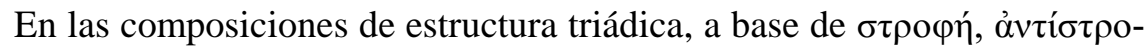

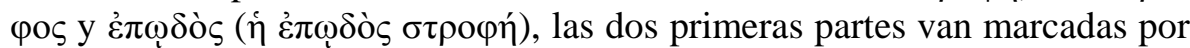

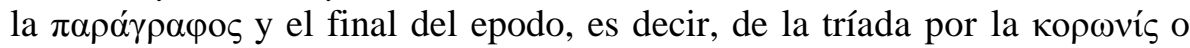

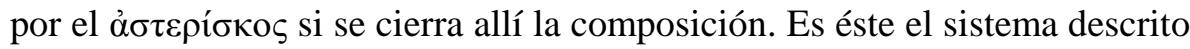
por Hefestión ${ }^{81}$, que coincide con la práctica de los papiros: el de Alcmán (P. Oxy. 2.387, s. I a.C.) presenta el texto organizado en $\kappa \tilde{\omega} \lambda \alpha$ y las estructuras triádicas marcadas como acabo de decir, o sea, a base de parágrafos y corónide al final ${ }^{82}$.

En esta labor editora el análisis detenido de la estructura métrica y de las debidas correspondencias entre unas partes y otras detectaba, por ejemplo, interpolaciones, que eran condenadas con un óbelo al margen. No faltaron tampoco descuidos o malentendidos en esta labor de Aristófanes o de los primeros filólogos; equivocaciones, no frecuentes, por cierto, pero que fue-

78 1968, pp. 334 ss., de donde tomo las observaciones siguientes.

79 La tradición que luego se consolidará de todas estas marcas aparece recogida, por

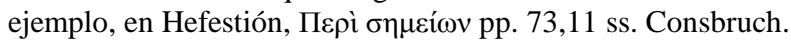

80 Es lo que se observa en su edición de Alceo: Hephaestio, p. 74,11 ss. Consbruch.

8173,18 ss. Consbruch.

82 El papiro de los Peanes de Píndaro (P. Oxy. 841) y, en menor medida, los de Baquílides reflejan espléndidamente la técnica editorial implantada por Aristófanes. Bien es verdad que los papiros no presentan una consecuencia absoluta y total en el empleo de estas marcas y que el asterisco se fue haciendo cada vez menos frecuente: el epodo final del Pean V aparece marcado con una corónide y un óbelo; el principio del Pean VI, con un signo de separación interpretable como un asterisco. Cf. Snell, Bacchyl., praef., p. 13, citado por Pfeiffer 1968, p. 335 .

EMERITA (EM) LXXIII 2, julio-diciembre $2005 \quad$ pp. 303-351 ISSN 0013-6662 
ron luego transmitidas fielmente de generación en generación ${ }^{83}$.

Aristófanes quedó ya para siempre como el responsable principal de la

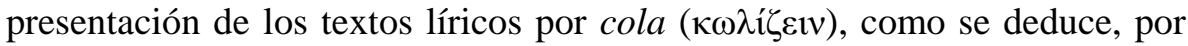
ejemplo, de estas palabras de Dionisio de Halicarnaso, en las que se contraponen los miembros de la poesía a los de la prosa artística:

Permíteme que llame 'miembros' no a aquéllos mediante los cuales Aristófanes o alguno de los otros métricos dispuso los poemas líricos, sino a aquéllos mediante los cuales la naturaleza exige que se divida el discurso y los muchachos de los rétores dividen los períodos ${ }^{84}$.

De la mélica sean los siguientes versos de Simónides. Están escritos conforme a las pausas de la lecturas, no como los miembros que establecían Aristófanes o algún otro, sino de los que reclamaría la prosa" ${ }^{85}$.

La colometría de Aristófanes quedó como algo canónico entre los métricos y fue repetidada una y otra vez durante toda la Antigüedad tardía y durante época bizantina; entonces recibirá algunas modificaciones por obra sobre todo de Triclinio. Hay que esperar, sin embargo, a la métrica moderna ${ }^{86}$ para asistir a una reorganización interna de las estrofas, al ser reconocidos en el interior de ellas como unidades métricas y articulatorias básicas

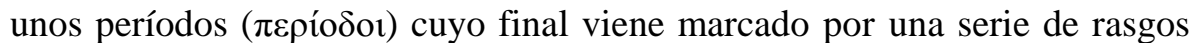
como el límite de palabra, el hiato o la indiferencia silábica; rasgos que, en cambio, no se dan en los límites de los miembros ( $\kappa \tilde{\omega} \lambda \alpha)$ que componen dichos períodos ${ }^{87}$.

\section{La edición de la poesía dramática.}

La labor filológica de Aristófanes de Bizancio, siguiendo probablemente la huella de algunos antecesores, alcanzó también a la poesía dramática, cuyas partes corales trató de organizar con la misma técnica colométrica, cosa que hasta entonces no se había hecho. Las partes recitadas, por lo general trímetros yámbicos, pero también algunos otros versos más largos, se pre-

83 Ejemplos de todo ello en Pfeiffer 1968, pp. $335 \mathrm{~s}$.

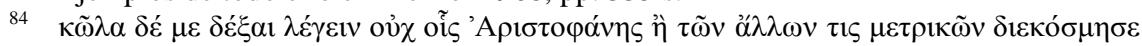

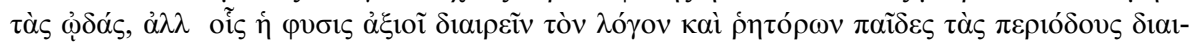
рои̃бı: Comp. uerb. XXII 156, p. 102,1 Usener-Radermacher.

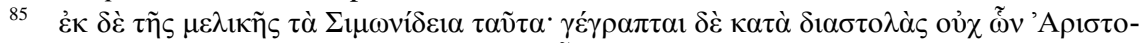

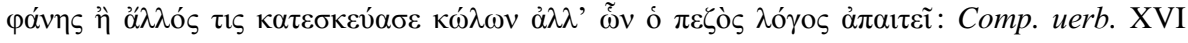
221, p. 140,18 ss. Usener-Radermacher.

${ }^{86}$ Por ejemplo, a Boeck 1811.

87 Ejemplos e indicaciones bibliográficas sobre estas posibles revisiones de las antiguas colometrías por parte de la métrica moderna pueden encontrarse en Pfeiffer 1968, pp. 337 s.

EMERITA (EM) LXXIII 2, julio-diciembre $2005 \quad$ pp. 303-351 ISSN 0013-6662 


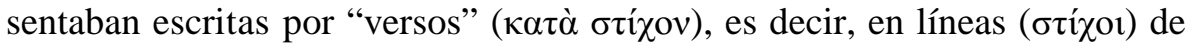
igual longitud, al modo de los hexámetros de la épica.

Trabajó Aristófanes sobre Menandro, autor por el que sentía una extraordinaria admiración, y es razonable pensar, con Pfeiffer, que se ocupó también del texto de otros autores de la "comedia antigua", como Cratino o Éupolis ${ }^{88}$.

La tragedia, en cambio, no parece haber suscitado tanto la atención de los filólogos y eruditos del siglo III. Tzetzes hace referencia a la $\delta ı o ́ \rho \theta \omega \sigma ı \varsigma ~ l l e v a-$ da a cabo por Alejandro de Etolia. Galeno ${ }^{89}$ cuenta que Ptolomeo III pidió prestada la edición de los tres grandes trágicos que había sido encargada por Licurgo ${ }^{90}$ y depositada en los archivos públicos de Atenas con idea de obligar a los actores a seguir un texto oficial, libre de corruptelas; y cuenta también que dicha edición no fue luego devuelta, sino que permaneció en la biblioteca de Alejandría. No podemos determinar la entidad crítica de dicho texto, pero sí es probable que estuviera a disposición de Aristófanes de Bizancio desde el comienzo de su actividad. Los manuscritos medievales se hacen eco de posibles ediciones de trágicos llevadas a cabo por Aristófanes: alusiones a algunas variantes y $\sigma \eta \mu \varepsilon i ̃$ diacríticos suyos encontramos en los escolios a Eurípides. Los papiros dan pruebas también de un texto suyo de Sófocles. De Esquilo, en cambio, no hay ningún dato en este sentido ${ }^{91}$.

Por desgracia, de forma distinta a lo que ocurre con la poesía lírica, en este terreno de la poesía dramática no nos es dado conocer muchos detalles de la tarea llevada a cabo por Aristófanes de Bizancio. Las mencionadas referencias a él en los escolios a las comedias de Aristófanes ${ }^{92}$ no permiten precisar mucho sobre su tarea crítico-filológica: corrigió, al parecer, nombres corruptos, marcó versos consecutivos intercambiables con las mismas marcas ( $\sigma i ́ \gamma \mu \alpha$ y $\left.\alpha^{\prime} v \tau \imath \sigma i ́ \gamma \mu \alpha\right)$ que había empleado en su edición de la Odisea, advirtió faltas, etc.; no se alude, en cambio, a intervenciones suyas en la indicación de los cambios de interlocutor, cosa que se esperaría en un gran filólogo como él. En los papiros antiguos y en los manuscritos medievales el cambio de interlocutor va indicado generalmente con el signo de $\pi \alpha \rho \alpha ́ \gamma \rho \alpha \varphi \varsigma \varsigma$ y dos puntos; más tarde, tal vez recordando una antigua costumbre alejandrina ${ }^{93}$ se

88 Siguiendo en esto la línea de Licofrón (s. III a. C.).

89 Comm. Hipp. Epid. III, CMG V 10.2.1., p. 79,8.

90 Amigo de Aristóteles, al frente de las finanzas atenienses entre 338 y 326.

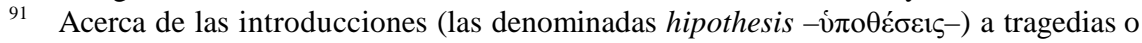
a comedias concretas atribuidas a Aristófanes, cf. Pfeiffer 1968, pp. 345 ss.

92 Que en este sentido no se diferencian mucho de los de Homero o Píndaro.

93 Cf. Lowe 1962, citado por Pfeiffer 1968, p. 341.

EMERITA (EM) LXXIII 2, julio-diciembre $2005 \quad$ pp. 303-351 ISSN 0013-6662 
indica dicho cambio mediante el nombre abreviado del personaje.

Tampoco podemos determinar hasta qué punto la colometría establecida por él en estos textos dramáticos es la que conservan luego los manuscritos que han llegado hasta nosotros. En este terreno hubo, al parecer, después de Aristófanes una actividad filológica intensa y continua que llegó a oscurecer su labor. Así, por ejemplo, en el códice Véneto, el más famoso de las comedias aristofánicas, el texto de las Nubes se cierra con un colofón que hace

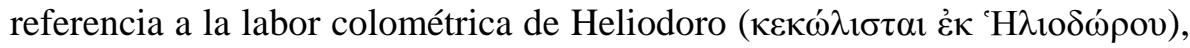
metricólogo alejandrino del siglo I, antecesor de Hefestión y uno de los más antiguos representantes del denominado "sistema alejandrino" de doctrina métrica ${ }^{94}$, que llevó a cabo una nueva edición de las comedias, en la cual, continuando la tradición de los grandes filológos alejandrinos de siglos

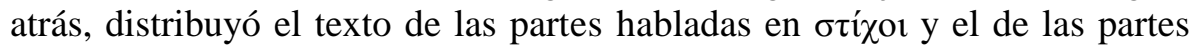
cantadas en $\kappa \tilde{\omega} \lambda \alpha$ (visualizando la estructura métrica a base de entradas -

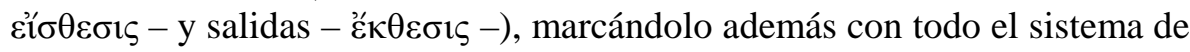

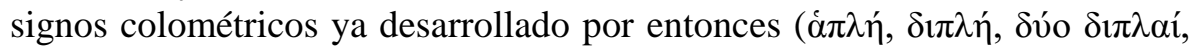

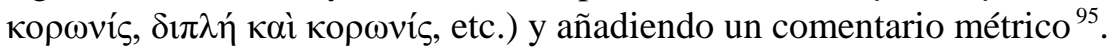

Autor también de un manual escolar de métrica del tipo del que nos ha llegado de Hefestión, la autoridad de Heliodoro es grande entre los tratadistas posteriores. Y otro tanto demuestran los restos que de su análisis de las comedias de Aristófanes han transmitido los escolios a este autor ${ }^{96}$. Se ha

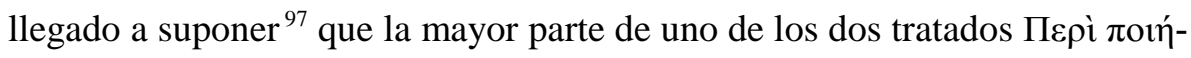

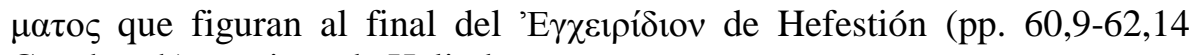
Consbruch) proviene de Heliodoro.

\section{La presentación escrita de los textos latinos en verso.}

También en latín la peculiar estructura del lenguaje versificado frente al prosaico no pudo menos que hacerse sentir a la hora de representar uno y otro por escrito.

Lo normal entre los latinos, tanto en inscripciones como en otro tipo de

\footnotetext{
Los grandes gramáticos, sin embargo, no parecen haberse preocupado mucho por estas marcas, lo cual puede ser, según Pfeiffer, la causa de la embarazosa inseguridad que muestran los manuscritos en este punto.

94 Cf., por ejemplo, Leo 1889; Leonhardt 1989b.

95 Cf. sobre todo ello Hense 1912 y estudios allí citados.

96 Una enumeración de referencias del tipo de la que acabo de citar puede verse en Hense, lug. cit.

97 Hense 1870, pp. 142 ss.
}

EMERITA (EM) LXXIII 2, julio-diciembre 2005 pp. 303-351 ISSN 0013-6662 
textos, era escribir cada verso en una línea; era ésta una práctica invariable cuando se trata de escritos en papiro o pergamino y habitual en las inscripciones. En la epigrafía, sin embargo, las limitaciones espaciales del soporte imponían a veces otra disposición e incluso hacían necesario recurrir a algún tipo de marca gráfica para reflejar la estructura métrica del texto ${ }^{98}$.

Si el verso no cabía entero en una línea lo más efectivo y frecuente era que al pasar a la línea siguiente se sangrara el texto restante ${ }^{99}$. Pero si la disposición del texto era más confusa, se hacía necesario marcar de algún modo la especificidad del lenguaje versificado; Wingo ${ }^{100}$ en este sentido distinguía tres grupos de marcas: unas que indican separación entre verso y prosa, otras que indican cambio de metro y otras que marcan límite de verso.

Entre las primeras reconocía en el CIL un signo similar al sicilicus ( ' ${ }^{101}$, el espacio en blanco (indicando el comienzo del pasaje versificado), la diplé (>: indicando el final de dicho pasaje) o un signo parecido al parágraphos ( ${ }^{102}$ : que marca el principio y el final del pasaje).

Para indicar cambio de metro se encuentran empleados el signo de la $\mathrm{pa}$ rágraphos y un signo más o menos así $/$, colocado en el margen izquierdo.

Los límites de verso se marcan de nueve formas distintas: con un espacio en blanco, con una hedera (\$), con una virgula (/: es el recurso más común), con un signo que parece una variante de una virgula ( $]$ ), con el signo $\mathrm{J}$, con el signo $\mathrm{Y}$, con una marca parecida a $\uparrow$, con una especie de I tumbada $\mathrm{y}$, en las inscripciones tardías (que ya no emplean el punto para separar palabras), con un punto.

En los más antiguos códices que han llegado a nosotros con textos tanto en prosa como en verso los escribas parecen preocupados ante todo por señalar a base de una especial disposición del texto las unidades o divisiones mayores del mismo; luego se van introduciendo marcas para indicar pausas o subdivisiones dentro de dichas unidades.

98 Una exposición de la variada gama de recursos empleados a este efecto puede verse en Wingo 1972, pp. 140 ss.

$99 \quad C I L$ VI $20674=C L E$ 436. Aunque también en esto se pueden encontrar casos de confusión, en los cuales se practican dichos sangrados, pero sin que se los haga corresponder con la estructura métrica: CIL VI 7898 = CLE 1058; CIL VI $27852=$ = CLE 1225.

1001972.

101 CIL XIV $4195=$ = CLE 875, aunque en este caso no es posible determinar si lo que se marca es el comienzo de una cita.

102 Aunque Buecheler, CLE 105 y 1251 habla de una diplé.

EMERITA (EM) LXXIII 2, julio-diciembre $2005 \quad$ pp. 303-351 ISSN 0013-6662 
A partir de los siglos de la Antigüedad tardía dicha disposición del texto y dichas marcas se combinan como signos de "puntuación" en el sentido general del término.

Es en la Edad Media cuando vemos reestablecerse una distinción entre la "puntuación" de la prosa y la del verso. En la prosa la disposición del texto se emplea para indicar los comienzos y finales de unidades mayores de dicho texto: capítulos, párrafos; las marcas gráficas se reservan para las divisiones internas dentro de dichas unidades mayores: delimitar las sententiae y dejar bien claras las unidades de sentido (sensus). En el verso, en cambio, tanto la disposición del texto como las marcas gráficas se orientan a reflejar la forma métrica de dicho texto.

Téngase, sin embargo, en cuenta la tradicional relación entre período y verso: totus autem uersus periodus est, escribirá San Isidoro ${ }^{103}$; una relación tradicional en la teoría de métricos, rétores y gramáticos, que comparten términos y conceptos como periodus, colon, comma; una relación que, de suyo, responde a algo más profundo, pues al fin y al cabo período métrico (verso) y período retórico no son sino un trasunto del período rítmico-musical.

Además la propia denominación del período en el lenguaje versificado es

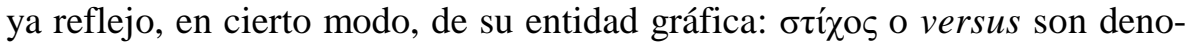
minaciones que suponen una identificación entre unidad rítmico-métrica y línea de escritura.

Muchos manuscritos medievales presentan ya el texto versificado dispuesto por versos, es decir, a base de un verso por renglón. A veces se añade una marca para indicar de manera redundante el fin de la unidad métrica, pero de ordinario basta con la disposición lineal, en cuyo caso la marca (por ejemplo, un punto alto - punctus eleuatus -) se emplea para representar el final de una unidad semántico-sintáctica.

Con frecuencia se emplean marcas al final de renglón para indicar, por ejemplo, fin de estrofa, pero a partir del siglo XIII se extiende la costumbre de colocar el signo de la parágraphos en el margen señalando el comienzo de una nueva unidad estrófica.

Hay manuscritos en los que los versos aparecen escritos uno tras otro sin distinción alguna, como si fueran prosa. Otras veces la distinctio uersuum se hace a base de las denominadas "mayúsculas internas", que indican el inicio de verso en la escritua continua. Estas mayúsculas iniciales de verso se em-

103 Orig. I 20,6.

EMERITA (EM) LXXIII 2, julio-diciembre 2005 pp. 303-351 ISSN 0013-6662 
plean incluso a veces, de manera redundante, en manuscritos que presentan el texto versificado dispuesto a base de un verso por línea.

A partir, sobre todo, del siglo IX abundan los códices en los que para la presentación de los versos se toma como referencia una doble línea vertical en el margen de la izquierda. Dicha doble línea vertical es un recurso atestiguado desde antiguo y normalmente empleado hasta el siglo VI con una fun-

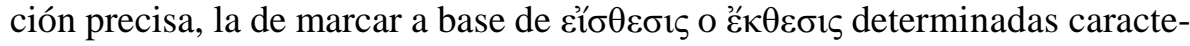
rísticas del texto o la presentación de dichas características, por ejemplo, las citas o la organización colométrica. Luego en los siglos VII y VIII, y quizá por obra de los monjes irlandeses, esta funcionalidad se va desdibujando ${ }^{104}$.

En lo que respecta al lenguaje versificado, ya en el códice Bembino de Terencio (Vat. lat. 3226 s. IV-V; Lowe CLA I 12; "A" en las ediciones) se constata que la doble línea del margen se emplea para distinguir tipos de verso: por ejemplo, Phorm. 560-566 septenarios trocaicos escritos a partir de la primera línea; 567-582 senarios yámbicos escritos a partir de la segunda. Esta funcionalidad de visualizar la polimetría se confirma ${ }^{105}$, en un sentido, con el hecho de que en los códices más antiguos (hasta el siglo VI inclusive) de Virgilio, de Lucano y de otros poetas hexamétricos se organizan los versos por referencia a una sola línea vertical; en otro sentido, positivo, confirman dicha funcionalidad otros manuscritos de Plauto (Palimpsesto Ambrosiano: CLA III 345, saec. V), Séneca (Palimpsesto Ambrosiano: CLA III 346, saec. V), Prudencio (CLA V 571a: saec. VI in.) y Próspero de Aquitania $(C L A \mathrm{~V} 609)^{106}$, todos ellos anteriores al siglo VII.

En último término ${ }^{107}$, este recurso no haría más que reflejar la práctica de las antiguas ediciones críticas, filológicas, que en su presentación de los textos se sometían a un sistema de signos (explícitos, es decir, a base de marcas gráficas, o implícitos, o sea, recurriendo simplemente a la presentación o visualización del texto) que dejaran patente a ojos del lector la peculiar articulación del texto editado: entre otras muchas cosas, si era en verso o en

104 Rafaelli 1984, p. 4, donde se pueden encontrar además otras referencias interesantes al respecto.

105 Cf. Rafaelli 1984, pp. 9 ss.

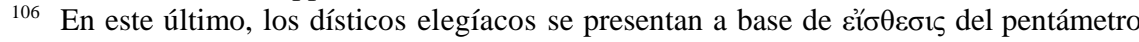
respecto del hexámetro; una práctica cuya antigüedad atestigua el papiro de Cornelio Galo Qasr Ibrim (Oxford, Ashmol. Mus., inv. 78-3-11 [L 1/2] y que, en cambio, ignoran numerosos papiros con elegías de Calímaco, en un amplio marco temporal antes y después de Cristo. Otro tanto ocurre con las inscripciones: mientras las latinas "sangran" el pentámetro, las griegas lo hacen unas veces sí y otras no: cf. Questa 1984, p. 396 y bibiografía allí indicada.

107 Cf. Questa 1984, pp. 340 ss. 
prosa, los distintos tipos de verso empleados, etc. Hay constancia ${ }^{108}$ de que la presentación del texto de Terencio y de Plauto se hizo muchas veces de acuerdo con un módulo ternario de distribución, en la cual los senarios yámbicos, al igual que los trímetros en las ediciones de obras griegas, constituían la norma o el punto de referencia: se los colocaba en el centro ideal de la columna del volumen o de la página del códice; a su izquierda, en ě́ $\theta \varepsilon-$ $\sigma \iota \varsigma$, se colocaban los versos largos (yámbicos, trocaicos, anapésticos) ${ }^{109}$; a su derecha, en $\varepsilon^{\prime} \delta \theta \varepsilon \sigma ı \iota$, , iban todos los versos más breves que el senario ${ }^{110}$. Los versos, por tanto, se iniciaban en tres líneas verticales distintas, dejando así visualizada, si no su distinta entidad métrica, sí al menos su diferente longitud. Tres verticales, se entiende, completamente ideales, lo cual no impide que en un papiro el copista pudiera tomar como referencia las propias fibras o que en un códice de pergamino se pudiera recurrir a marcarlas de forma más o menos evidente.

En cuanto a los versos largos, en los textos teatrales griegos eran casi todos trocaicos ${ }^{111}$; la decodificación del mensaje era, pues, fácil para el lector. En latín la situación era más compleja: los versos largos eran mucho más frecuentes, más variados e incluso se empleaban con frecuecia mezcla-

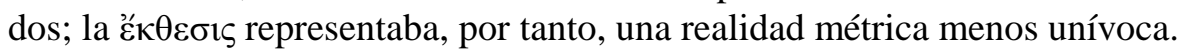

Los senarios centraban, como he dicho, la columna o la página. Sin embargo, Plauto presenta además amplios pasajes, incluso dialogados, en metros distintos del senario (por ejemplo, cuaternarios créticos o baquíacos) pero de la misma envergadura o longitud. Tales versos se alinean también con los senarios, de modo que, al igual que ocurre con los versos largos, tampoco es unívoca la indicación de esta línea central: por sí sola no decía al lector si tenía ante sí senarios o si tenía otro tipo de versos.

Y otro tanto ocurría con los versos cortos o cláusulas; la tercera línea que los organizaba a todos en $\varepsilon \grave{c} \sigma \theta \varepsilon \sigma 1 \varsigma$ no indicaba nada sobre la naturaleza del verso en cuestión.

Un panorama comparable, mutatis mutandis, a este de los textos de Terencio y Plauto ofrecen los de Prudencio o de Horacio ${ }^{112}$.

\footnotetext{
108 Questa, lug. cit.

109 Al igual que desde tiempos remotos se colocaban en las ediciones griegas de obras de teatro los tetrámetros trocaicos catalécticos y otros similares, aunque de uso excepcional.

110 También al igual que en griego.

111 Rara vez anapésticos y excepcionalmente yámbicos o dactílicos.

112 Cf. Questa 1984, respectivamente, pp. 349-365 y 365-395.
}

EMERITA (EM) LXXIII 2, julio-diciembre $2005 \quad$ pp. 303-351 ISSN 0013-6662 
En los manuscritos de Séneca trágico se ha estudiado también la configuración general de la página y, más en concreto, la disposición de los trímetros en las líneas y los procedimientos por los que en dicha disposición se marcan las $\alpha \dot{v} \tau \lambda \lambda \alpha \beta \alpha i$, es decir, los cambios de interlocutor en interior de verso ${ }^{113}$.

\section{La aclimatación en Roma de las prácticas y doctrinas filológicas.}

Ante la cuestión de cuándo se aclimató en Roma toda esta práctica de representar por escrito la articulación de los textos no hay datos para afirmar nada con seguridad. En lo que se refiere a la introducción en el ars grammatica de la doctrina de la puntuación a base de tres puntos a distintas alturas, se ha pensado en L. Elio Estilón (150-90 a.C.), que pudo haber coincidido en Rodas con Dionisio Tracio ${ }^{114}$. Lucilio (180-103 a. C.), cuyo interés por las cuestiones del lenguaje y la claridad de la escritura es de sobra conocido, es probable que se interesara por estas cuestiones. Y otro tanto hay que suponer de Varrón (116-27 a.C.), que, por ejemplo, en el De sermone Latino recomienda el uso de una marca especial para indicar la presencia en final de verso de una breuis in longo ${ }^{115}$. Pero de ninguno de los dos nos ha llegado ningún testimonio seguro al respecto.

Algo parecido ocurre con los gramáticos y ortógrafos de la última República y del primer Imperio; ni una sola referencia se encuentra en las colecciones de fragmentos de Funaioli ${ }^{116}$ y Mazzarino ${ }^{117}$. Aunque resulta inconcebible que ninguno de estos filólogos o lingüistas hiciera alusión al asunto; es más, debemos suponer que no era así, en la medida en que es posible reconocer que muchas ideas e incluso fragmentos de sus obras pasaron como herencia a la tradición y figuran en los escritos de los gramáticos tardíos que han llegado hasta nosotros. Bien es verdad que lo razonable es suponer que estos gramáticos tardíos tomaron de dicha tradición sólo pasajes que les resultaban de interés para las necesidades de la época y que dejaron, en cambio, a un lado toda referencia a sistemas de puntuación que ya por entonces se habían hecho obsoletos.

113 Cf. Monteleone 1989.

114 Cf. Habinek 1985, p. 50, n.1, con indicaciones bibliográficas al respecto.

115 De sermone Latino VII, fragm. 66 Goetz-Schoell (= 46 Funaioli): quare in huisce modi locis poni oportet notam I transversam inter syllabas, frequentius ad extremum versum senarium et similes, si pro longa brevem habebunt extremam

1161907.

1171955.

EMERITA (EM) LXXIII 2, julio-diciembre $2005 \quad$ pp. 303-351 ISSN 0013-6662 
El hecho es que estos gramáticos tardíos se hacen eco una y otra vez con llamativa unanimidad del sistema de puntuación que, procedente de territorio griego, terminó aclimatándose en los manuales escolares romanos. Pero este sistema, según Wingo ${ }^{118}$, poco tiene que ver con el sistema latino de puntuación de época clásica. Más bien es deudor del sistema de puntuación desarrollado para los textos griegos en los círculos filológicos de Alejandría.

Remio Palemón (5-65 p.C.) pudo ser el introductor en la gramática romana de esta doctrina griega sobre la puntuación ${ }^{119}$; su figura habría sido también en este punto, como en tantos otros, esencial para implantar en la gramática escolar romana (ars grammatica) lo que ya estaba consolidado en la

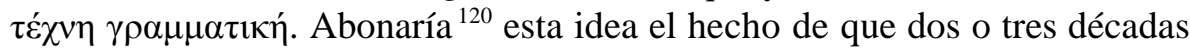
después de su muerte se documenta el primer empleo de distinguere con el sentido de "puntuar".

En efecto, en la práctica filológica de Marco Valerio Probo (20-80 p. C.) ya se entendía ${ }^{121}$ el distinguere (puntuar) como tarea específica distinta del emendare (corregir) y del adnotare (adjuntar las marcas críticas de la tradición filológica alejandrina). Suetonio describe la labor filológica de Probo sobre los textos de autores antiguos, la mayor parte de los cuales se hallaban en mal estado, no sólo como depuración (emendare) de errores e interpolaciones y como oportuna anotación (adnotare), sino también como 'distinción' o señalización (distinguere):

M. Valerio Probo, el de Berito (hoy Beirouth) anduvo mucho tiempo tras el grado de centurión, hasta que hastiado se dedicó a los estudios. Había leído en la provincia ciertos viejos librillos en casa del maestro de primeras letras, al mantenerse hasta la fecha allí el recuerdo de los antiguos y no haberse borrado por completo como en Roma. Al entrarle el deseo de repasarlos con más atención y luego de conocer otros, a pesar de advertir que todos eran desechables y motivo más de ofensa que de gloria o provecho para los lectores, no dejó de permanecer en su propósito y muchos ejemplares que fue reuniendo se ocupó de corregirlos, distinguirlos (es decir, marcarlos, puntuarlos) y anotarlos (es decir, con los signos diacríticos correspondientes) ${ }^{122}$.

118 1972, p. 22, que, a su vez, remite a Thompson 1912.

119 Cf. Barwick 1922, pp. 145 s., 165; Müller 1964, p. 56.

${ }^{120}$ Cf. Müller 1964, pp. 56 s.

121 La labor de Probo en la puntuación de los textos clásicos latinos será luego frecuentemente mencionada por los comentaristas tardíos; por ejemplo, Donato, In Ter. Eun. 46: non eam Probus distinguit ..., Servio, In Verg. Aen. X 173 subdistingui uult...

122 Suet., Gramm. 24: M. Valerius Probus Berytius diu centuriatum petiit donec taedio ad studia se contulit. legerat in provincia quosdam veteres libellos apud grammatistam, durante adhuc ibi antiquorum memoria necdum omnino abolita sicut Romae. hos cum diligentius repetere atque alios deinceps cognoscere cuperet, quamvis omnes contemni magisque

EMERITA (EM) LXXIII 2, julio-diciembre 2005 pp. 303-351 ISSN 0013-6662 
$\mathrm{Si}$, como parece, remonta a Suetonio el fragmento sobre los signos diacríticos conservado en el códice Parisinus Latinus 7530, al que me referiré más adelante, habría que retrotraer como mínimo a esa época el empleo del simplex ductus (>) como signo de puntuación ${ }^{123}$, un signo que, si se atiende al testimonio de San Isidoro, parece identificarse con el paragraphus ${ }^{124}$.

\section{La tradición gramatical en época tardía y medieval.}

Como se recordará, dije más arriba que hay indicios suficientes de que, en general, las marcas empleadas por los filólogos para reflejar en los textos la articulación rítmico-métrica de las obras en verso fueron siempre vistas como algo próximo a los demás signos gráficos dedicados a recoger en la escritura el componente prosódico del habla, tanto en el nivel de las palabras (los signos "de acentuación") como en el de la frase (los signos "de puntuación"). De este modo acentuación, puntuación y anotación se vieron integradas como partes o aspectos de un único sistema general de grafemas que cubrían los aspectos del habla, del sonus uocis, no cubiertos por las letras del alfabeto. De este modo en la estructura habitual de la parte primera de los manuales de gramática, donde en estrecha vecindad con los capítulos dedicados a la

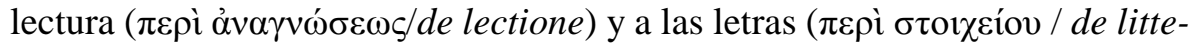
$\mathrm{ra}$ ) aparecen de ordinario los dedicados a los acentos o prosodemas de pala-

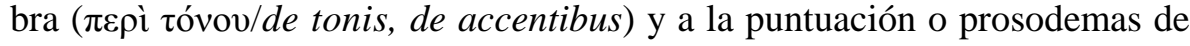
frase ( $\pi \varepsilon \rho \grave{~} \sigma \tau \imath \gamma \mu \tilde{\eta} \varsigma / d e$ distinctione, de posituris), ambos además en íntima relación, terminaron incorporándose otros sobre la anotación de los textos (de notis).

El libro primero de las Etimologías de San Isidoro da un buen ejemplo de esto: de los capítulos 18 (De accentibus) y 19 (De figuris accentuum, donde ya se incluyen no sólo los acentos, sino las diez prosodias de la tradición gramatical antigua), pasa en el 20 (De posituris) a lo que nosotros entendemos por "puntuación" y de aquí, en el 21 (De notis sententiarum), como él

obprobrio legentibus quam gloriae et fructui esse animadverteret, nihilo minus in proposito mansit multaque exemplaria contracta emendare ac distinguere et adnotare curavit.

${ }^{123}$ GLK VII 5353 ss: simplex ductus inter versus ponebatur ad separandas res a rebus quae inconexa currerent, quem ad modum in catalogo, cum loca a locis aut regiones a regionibus, et in agone, cum praemia a praemiis, certamina a diversis certaminibus separantur.

124 Isidoro (Orig. I 21,8), según veremos, asigna estas funciones al parágraphos: Paragraphus ponitur ad separandas res a rebus, quae in conexu concurrunt, quemadmodum in Catalogo loca a locis et [regiones a] regionibus, in Agone praemia a praemiis, certamina a diversis certaminibus separantur. - Sobre todo ello, cf. Müller 1964, pp. 62 s.

EMERITA (EM) LXXIII 2, julio-diciembre $2005 \quad$ pp. 303-351 ISSN 0013-6662 
mismo escribe, a "determinados signos gráficos que existieron en los más célebres de los autores y que los antiguos adjuntaron a poemas e historias (es decir, a verso y a prosa) para marcar los escritos". Entiende Isidoro estos "signos" como "figuras características, puestas a modo de letras para hacer patente una determinada razón de una palabra, de unas frases o de unos versos" ${ }^{125}$. Son, según él, un total de veintiséis. A ellas añadirá en capítulos sucesivos (22-26) otras marcas de taquigrafía, de siglas jurídicas, militares, de lenguajes cifrados, e incluso otras señales que se hacen con los dedos o con los ojos, con las que también se habla en cierto modo. De aquí terminará pasando a hablar de ortografía (cap. 27 De orthographia) y luego de cuestiones pertenecientes a las otras partes de la gramática preconizadas, como vimos antes, en la Té $\chi v \eta$ de Dionisio Tracio: De analogia (28), De etymologia (29), De glossis (30), etc., etc.

Este pasaje de Isidoro figura en los folios 154 y siguiente del codex Parisinus 7530 (del año 780), en cuyos folios 28 y 29 se recoge también otro anónimo que, tras varios estudios y ediciones anteriores ${ }^{126}$, incluyó Keil en el tomo VII de los Grammatici, pp. 533 ss. ${ }^{127}$ : Notae XXI quae versibus apponi consuerunt. Ambos textos, además de testimoniar la pervivencia secular del sistema que iniciaron los primeros filólogos de Alejandría, dan cuenta del resultado de su evolución a lo largo y ancho de la Antigüedad Tardía y de la Edad Media occidental.

Estos signos, como acabamos de ver, los considera San Isidoro garantizados por los mejores autores (apud celeberrimos auctores) y los entiende dirigidos a marcar (distinctio, nótese el término) el sentido (notae sententiarum) o la entidad de las palabras, de las frases y de los versos (ad demonstrandam unamquamque verbi sententiarumque ac versuum rationem). $\mathrm{Y}$ ello tanto en los textos en verso como en los en prosa (ad distinctionem scripturarum carminibus et historiis adposuerunt), si bien acto seguido los enumera como referidos exclusivamente al verso (notae autem versibus adponuntur numero viginti et sex).

125 Orig. I 21,1: Praeterea quaedam scripturarum notae apud celeberrimos auctorum fuerunt, quasque antiqui ad distinctionem scripturarum carminibus et historiis adposuerunt. Nota est figura propria in litterae modum posita, ad demonstrandam unamquamque verbi sententiarumque ac versuum rationem.

126 Entre ellas la que antes he mencionado de Reifferscheid, que incluyó este texto entre las reliquiae de Suetonio, en la idea de que el fragmento podía remontar al historiador; algo que Keil siguió considerando probable; cf. también Müller 1964, p. 62.

127 Cf. también Funaioli, GRF, p. 54, bajo Lucius Aelius Stilo.

EMERITA (EM) LXXIII 2, julio-diciembre $2005 \quad$ pp. 303-351 ISSN 0013-6662 
El fragmento anónimo es más explícito en lo que respecta a la tradición antigua, tanto griega como romana, equiparando en este sentido la labor de Probo en Roma con la de los grandes alejandrinos, como Aristófanes o Aristarco. Un primer pasaje (534,4 ss.) en donde hace referencia a los gramáticos o filólogos que emplearon estos signos aparece corrupto y ha sido objeto de todo tipo de conjeturas ${ }^{128}$; luego en la descripción de algunos de los signos hace referencia al empleo que de ellos hicieron estos antiguos filólogos.

Los signos que se enumeran tanto en Isidoro como en el otro fragmento anónimo son los siguientes:

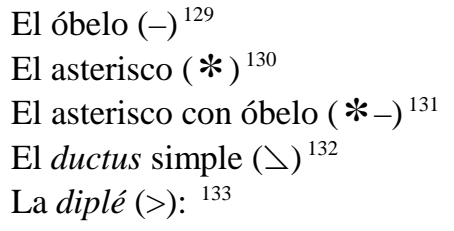

128 Cf. Keil, nota ad loc.

129 Anon. (1), GLK VII 534,7 ss.: obelus versibus apponitur hac causa. Pisistratus quondam Atheniensium tyrannus inordinata et confusa adhuc poesi Homeri praemio sollicitare proposuit eos qui eam ordinarent iisque praemii nomine in singulos versus singulos obolos constituit. mercede multi inducti pauperes, quibus ingenium affluebat, quoniam aut invenire aur disponere $\dagger$ debebat non poterant, fingendo plurimos versus operis nobilitatem corruperunt. unde evenit, ut postea prudentiores viri, quorum summus in hac re fuit Aristarchus, quotiens inprobarent versus quasi aut malos aut non Homericos, obelo potissimum notandos existimarunt. nam et ipsius Homeri proprios sed non eo dignos eadem hac nota condemnarunt. - Isid., orig. I 21,3: Obolus, id est, virgula iacens, adponitur in verbis vel sententiis superflue iteratis, sive in his locis, ubi lectio aliqua falsitate notata est, ut quasi sagitta iugulet supervacua atque falsa confodiat. Sagitta enim Graece ỏße $\lambda$ ó dicitur.

${ }^{130}$ Anon. (2), GLK VII 534,17 ss.: asteriscus Aristophanes apponebat illis locis quibus sensus deesset, Aristarchus autem ad eos, qui in hoc puta loco positi erant, cum aliis scilicet non recte ponerentur. Item Probus et antiqui nostri. — Isid., orig. I 21,2: Asteriscus adponitur in his quae omissa sunt, ut inlucescant per eam notam, quae deesse videntur. Stella enim

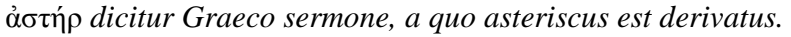

131 Anon. (3), GLK VII 535,1: asteriscus cum obelo propria nota est Aristarchi. utebatur autem ea in his uersibus, qui non suo loco positi erant. item antiqui nostri et Probus. - Isid., orig. I 21,7: Asteriscus cum obolo. Hanc proprie Aristarchus utebatur in his versibus, qui non suo loco positi erant

132 Cf. paragraphus en Isidoro. - Anon. (4). GLK VII 5353 ss.: simplex ductus inter uersus ponebatur ad separandas res a rebus quae inconexa currerent, quem ad modum in catalogo, cum loca a locis aut regiones a regionibus, et in agone, cum praemia a praemiis, certamina a diuersis certaminibus separantur.

${ }_{133}$ Anon. (5), GLK VII 535,7 ss.: diplen aperistikton primus Leagoras Syracusanus apposuit Homericis versibus ad separationem Olympi a caelo, proprie Olympum ab eo pro monte

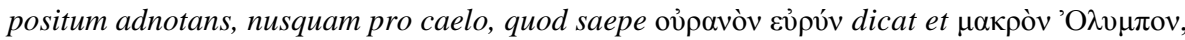

EMERITA (EM) LXXIII 2, julio-diciembre $2005 \quad$ pp. 303-351 ISSN 0013-6662 


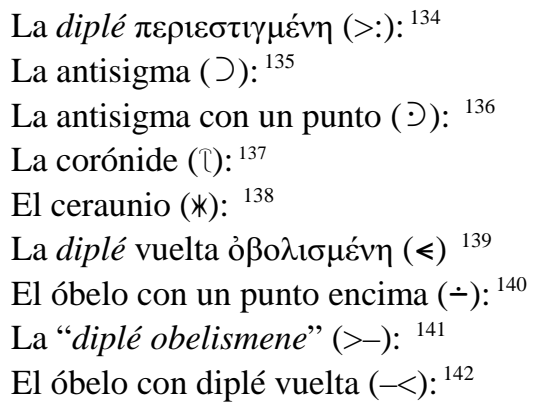

neque e contrario epitheta permutet. ponebat autem tam ad montis significationes quam ad caeli: utrimque manifestatur voluntas eius. usus et in multis Aristarchus, nunc ea quae praeter consuetudinem tam uitae nostrae quam ipsius poetae apud eum inuenirentur adnotans, nunc proprias ipsius figuras, interdum ea in quibus copiosus est, rursus quae semel apud eum ponerentur. similiter in nostris auctoribus Probus. — Isid. I 21,13: Diple. Hanc scriptores nostri adponunt in libris ecclesiasticorum uirorum ad separanda uel [ad] demonstranda testimonia

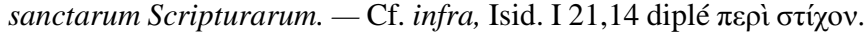

${ }^{134}$ Anon. (6), GLK VII 535,16: diple periestigmene apponebatur in his quae Zenodotus Ephesius non recte adiecerat aut detraxerat aut permutaverat. et nostri ea usi sunt. - Isid.,

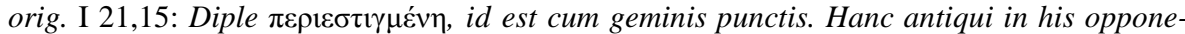
bant quae Zenodotus Ephesius non recte adiecerat, aut detraxerat, aut permutaverat. In his et nostri ea usi sunt.

135 Anon. (7), GLK VII 535,18: antisigma ponebatur ad eos versus quorum ordo permutandus erat. sic et in nostris auctoribus invenitur. — Isid., orig. I 21,11: Antisigma ponitur ad eos versus quorum ordo permutandus est. Sic et in antiquis auctoribus positum invenitur.

136 Anon. (8), GLK VII 535,20: antisigma cum puncto ponebatur, cum eiusdem sensus versus duplices essent et dubitanter, qui potius legendi. sic et apud nostros. - Isid., orig. I 21,12: antisigma cum puncto ponitur in his locis ubi in eodem sensu duplices versus sunt, et dubitatur qui potius eligendus sit.

137 Anon. (9), GLK VII 535,22: coronis tantum in fine libri posita invenitur. - Isid., orig. I 21,26: Coronis nota tantum in fine libri adponitur.

138 Anon. (10), GLK VII 535,23: ceraunium ponitur, quotiens multi versus inprobantur, ne per singulos obelentur. - Isid., orig. I 21,21: ceraunium ponitur quotiens multi versus inprobantur, nec per singulos obolatur; кعраv́vıov enim fulmen dicitur

139 Anon. (11), GLK VII 536,1: aversa obelismene $\dagger$ in ore ponitur, quae ad aliquid respiciunt ut 'nosne tibi fluxas Phrygiae' - Isid., orig. I 21,18: Adversa cum obolo ad ea ponitur quae ad aliquid respiciunt, ut (Virg. Aen. X 88): 'Nosne tibi ... Phrygiae res vertere fundo / conamur? nos? an miseros qui Troias Achivis / obiecit?

${ }^{140}$ Anon. (12), GLK VII 536,3: obelus cum puncto ad ea de quibus dubitatur tolli debeant necne. - Isid., orig. I 21,4: obolus superne adpunctus ponitur in hisdem, de quibus dubitatur utrum tolli debeant necne adponi. [Falsitate notatum est]

${ }_{141}$ Anon. (13), GLK VII 536,4: diple obelismene ad separandas in comoediis et tragoediis periodos. - Isid., orig. I 21,16: diple ỏßoגı $\sigma \mu \varepsilon \dot{v} \eta$ interponitur ad separandos in comoediis vel tragoediis periodos.

${ }^{142}$ Anon. (14), GLK VII 536,5: obelus cum aversa, quotiens strofae antistrofos infertur.

EMERITA (EM) LXXIII 2, julio-diciembre $2005 \quad$ pp. 303-351 ISSN 0013-6662 
La diplé con óbelo encima $(>)^{143}$

La diplé normal e invertida con óbelos encima $(\overline{><})^{144}$

La "chi-rho" $(\notin){ }^{145}$

La "phi.rho" (Ф) 146

El ancla hacia arriba $(T)^{147}$

El ancla hacia abajo $(\downarrow)^{148}$

Además de estas marcas Isidoro enumera y describe las siguientes:

El lemnisco $(\div){ }^{149}$

El antígrafo con un punto $(\dot{Y})^{150}$

El parágrafo $\left(\ulcorner){ }^{151}\right.$

La positura $(\neg):^{152}$

La crifia $(\cup):^{153}$

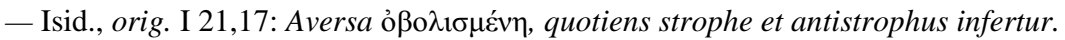

${ }_{143}$ Anon. (15), GLK VII 536,6: diple superne obelata ponitur ad condicionem locorum uel temporum uel personarum mutata. - Isid., orig. I 21,19: diple superne obolata ponitur ad conditiones locorum ac temporum personarumque mutatas.

144 Anon. (16), GLK VII 536,8: recta et auersa superne obelatae ponuntur cum eadem * significant similemque sequentem esse. - Isid., orig. I 21,20: diple recta et aduersa superne obolata ponitur finita loco suo monade, significatque similem sequentem quoque esse.

${ }_{145}$ Anon. (17), GLK VII 536,10: chi et ro. haec sola ex uoluntate unius cuiusque ad aliquid adnotandum ponitur. - Isid., orig. I 21,22: $C<h>$ rismon. Haec sola ex uoluntate uniuscuiusque ad aliquid notandum ponitur.

146 Anon. (18), GLK VII 536,10: fi et ro. haec apponuntur, quotiens uel emendatio uel

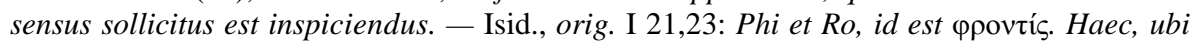
aliquid obscuritatis est, ob sollicitudinem ponitur.

147 Anon. (19), GLK VII 536,14: ancora superior ad aliquod praecipue dictum. - Isid., orig. I 21,24: Anchora superior ponitur ubi aliqua res magna omnino est.

148 Anon. (20), GLK VII 536,15: ancora inferior ad humilius uel inconuenientius quid enuntiatum. - Isid., orig I 21,25: Anchora inferior, ubi aliquid uilissime vel inconvenientius denuntiatum est.

149 Isid., orig I 21,5: Lemniscus, id est, uirgula inter geminos punctos iacens, opponitur in his locis, quae Sacrae Scripturae interpretes eodem sensu, sed diuersis sermonibus transtulerunt. - Anon: lo enumera como obelus adpunctus, pero luego lo omite en la descripción (en su lugar aparece el anterior obelus cum puncto).

150 Isid., orig. I 21,6: Antigraphus cum puncto adponitur ubi in translationibus diuersus sensus habetur.

151 Cf. simplex ductus en Anon. — Isid., orig. I 21,8: Paragraphus ponitur ad separandas res a rebus, quae in conexu concurrunt, quemadmodum in Catalogo loca a locis et [regiones a] regionibus, in Agone praemia a praemiis, certamina a diuersis certaminibus separantur.

152 Isid., orig. I 21,9: Positura est figura paragrapho contraria et ideo sic formata, quia sicut ille principia notat, ita ista fines a principiis separat.

153 Isid., orig. I 21,10: Cryphia, circuli pars inferior cum puncto, ponitur in his locis, ubi quaestio dura et obscura aperiri uel solui non potuit.

EMERITA (EM) LXXIII 2, julio-diciembre $2005 \quad$ pp. 303-351 ISSN 0013-6662 


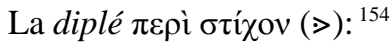

El álogo ( ( ): ${ }^{155}$

La serie la cierra Isidoro (I 21,28) aludiendo a otros signos que se colocan en los extremos de las páginas para remitir al lector a otros lugares o palabras:

Fiunt et aliae notulae librorum pro agnoscendis his quae per extremitates paginarum exponuntur, ut, ubi lector in liminare huiusmodi signum inuenerit, ad textum recurrens eiusdem semonis uel uersiculi sciat esse expositionem, cuius similem superiacentem notam inuenerit.

El fragmento anónimo concluye ( $G L K$ VII 536, 16-23) con la enumeración de una nueva serie de marcas denominadas NOTAE SIMPLICES:

\footnotetext{
$>$ bis dictum. $\supset$ alienus uersus $\mathrm{F}$ metafrasis latina. $\Phi$ metafrasis graeca. $\mathrm{M}$ malum metrum aut aprepes. $\Pi$ contra historiam. $\Theta$ superuacuus. - repugnans. $\mathrm{H}^{*}$ recte positus et pugnanti contrarius. - praepositum sine consequente. - consequens sine praeposito. $<$ alienus et superuacuus. $\Phi) \Phi \%$ graeca metrafrasis et bis dictum et repugnans. $\Phi \mathrm{P}$ graeca metafrasis et repugnans. $\Phi \mathrm{F}$ metafrasis graeca et latina.

F. de notis Probianis.
}

\section{BIBLIOGRAFIA MENCIONADA}

Barwick, K, 1922: Remmius Palaemon und die römische Ars Grammatica, Leipzig.

Büchner, K., 1961: "Überlieferungsgeschichte der lateinischen Literatur des Altertums”, en Geschichte der Textüberlieferung, Zurich, pp. 310-422.

Cohn, L., 1895: “Aristarchos” REII,I cols. 862-873

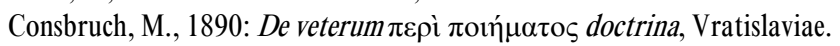

Del Grande, C., 1960: Le metrica greca, Torino.

Desbordes, F., 1995: Concepciones sobre la escritura en la Antigüedad romana, trad. esp. A.L.Bixio, Barcelona.

Diels, H., 1882: "Stichometrisches", Hermes 17 (1882) 377-384.

Ernout, A.-Meillet, A., 1967: Dictionnaire étymologique de la langue latine, Paris $\left(4^{\mathrm{a}}\right)$

Frisk, H., 1960: Griechisches etymologisches Wörterbuch, Heidelberg.

Funaioli, H., 1907: Grammaticae Romanae fragmenta collegit H. F., Lipsiae.

Gardthausen, V., 1911: Griechische Paläographie I: Das Buchwesen in Altertum und in Byzantinischen Mittelalter, Leipzig $\left(2^{\mathrm{a}}\right)$.

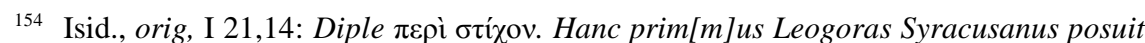
Homericis uersibus ad separationem Olympi a caelo. - Cf. Anon. diplé.

155 Isid., orig. I 21,27: Alogus nota [quae] ad mendas adhibetur.

EMERITA (EM) LXXIII 2, julio-diciembre 2005 pp. 303-351 ISSN 0013-6662 
Gardthausen, V., 1913: Griechische Paläographie II: Die Schrift, Unterschriften und Chronologie im Altertum und Byzantinischen Mittelalter, Leipzig $\left(2^{\mathrm{a}}\right)$.

Graux, Ch., 1878: "Nouvelles recherches sur la stichométrie", Revue de Philologie 2 (1878) 97-143.

Graux, Ch., 1893: Les articles originaux, Paris.

Gleditsch, H., 1901: Metrik der Griechen und Römer, München $\left(3^{\mathrm{a}}\right)$.

Gudeman, A., 1922: "Kritische Zeichen”, RE XI,2, cols. 1922-1927.

Habinek, T.N., 1985: The Colometry of Latin Prose, Berkeley.

Hense, O., 1870: Heliodoreische Untersuchungen, Leipzig.

Kretschmer, P., 1918: "Litteraturbericht für das Jahr 1915. Griechisch", Glotta 9, 1917-1918, pp. 209236.

Lameere, W., 1960: Aperçus de paléographie homérique, Paris, Les publications de Scriptorium IV, 1960, pp. 190-204

La Roche, J., 1862: Text, Zeichen und Scholien des berühmten Codex Venetus zur Ilias, Weisbaden.

Lausberg, H., 1960: Manual de retórica literaria, trad. esp J. Pérez Riesco, vols. I-III, Madrid, 1966.

Luque Moreno, J. 1994: Arsis, thesis, ictus. Las marcas del ritmo en la rítmica y en la métrica antiguas, Granada.

Luque Moreno, J., 1995: De pedibus, de metris. Las unidades de medida en la rítmica y en la métrica antiguas, Granada.

Luque Moreno, J., 1998: “Vox (sonus), sermo, carmen, cantus, versus, oratio”, en B. García-Hernández (ed.), Estudios de Lingüística latina, Madrid, 1998, pp. 971-985.

Luque Moreno, J., 1999: “Caesura, colon, carmen, melos”, en J. Luque-P.R.Díaz, Estudios de métrica latina, Granada, vol. II, pp. 519-538.

Luque Moreno, J., 2000: "La retórica antigua y la articulación del lenguaje", en J. Ribeiro (ed.), A retórica Greco-Latina e a sua Perenidade, Porto, 2000, Vol. I 305-323.

Luque Moreno, J., 2001: “Numerus. la articulación rítmica del lenguaje”, Actas del X Congreso Español de Estudios Clásicos, vol. II, pp. 493-527.

Luque Moreno, J., 2002: “Aftonio y la articulación del hexámetro" Florentia Iliberritana 13, 2002, pp. 103-115.

Luque Moreno, J., 2003: "Articulación métrica y articulación sintáctica: los versos del teatro de Séneca", Florentia Iliberritana 14, 2003, pp. 121-171.

Luque Moreno, J., 2004: “De tome sive incisione versuum: Aftonio y las cesuras del hexámetro", en E. di Lorenzo (ed.), L'esametro greco e latino, Nápoles, 2004, pp. 113-135.

Mariner, S., 1971: "Carácter convencional del ritmo", en Coloquios de historia y estructura de la obra literaria, Madrid.

Mazzarino, A., 1955: Grammaticae Romanae Fragmenta aetatis Caesareae, collegit A. M., Augustae Taurinorum.

Mommsen, Th., 1886: "Zur lateinischen Stichometrie”, Hermes 21, 1886, pp. 142-156.

Monteleone, C., 1989: La pagina e la sapienza. Memoria sulle "antilabai” nei manoscritti senechiani”, Fasano.

Müller, R.-W., 1964: Rhetorische und syntaktische Interpunktion. Untersuchungen zur Pausenbezeichnung in antiken Latein (Tesis doctoral), Tubinga.

Pokorny, F., 1969 Indogermanisches etymologisches Wörterbuch, Viena.

Questa, C., 1984: "Il Metro e il Libro. Per una semiologia della pagina scritta di Plauto, Terenzio, Prudenzio, Orazio", en Questa-Rafaelli 1984, pp. 337-396.

Questa, C.-Rafaelli, R., 1984: Il libro e il testo, Atti del convegno internazionale, Urbino 20-23 settembre 1982, Urbino.

EMERITA (EM) LXXIII 2, julio-diciembre $2005 \quad$ pp. 303-351 ISSN 0013-6662 
Rafaelli, R., 1984: "La pagina e il testo. Sulle funzioni della doppia rigatura verticale nei codici latini antiquiores", en Questa-Rafaelli 1984, pp. 1-24.

Reifferscheid, A. (ed.), 1860: C.Suetoni Tranquilli praeter Caesarum libros reliquiae, Lipsiae (= Hildesheim 1971).

Sandys, J.E., 1920: A History of Classical Scholarship, I, Cambridge $1920\left(3^{\text {a }}=\right.$ New York 1967)

Schultz, G., 1885: Quibus auctoribus Aelius Festus Aphtohinus de re metrica usus sit, (diss.), Bratislaviae.

Studemund, G., 1886: Anecdota varia Graeca musica metrica grammatica, Berolini.

Thompson, E. M., 1912, An Introduction to Greek and Latin Palaeography, Oxford.

Walde, A.-Hofmann, J.B., 1938: Lateinisches etymologisches Wörterbuch, Heidelberg.

Westphal, R., 1887: Westphal-Gleditsch, H., Theorie ..., Vol. III 1: Allgemeine Theorie der griechische Metrik, Leipzig.

Westphal, R., 1889: Westphal - Rossbach, A., Theorie ..., Vol. III 2: Griechische Metrik, Leipzig.

Wingo, E. Otha, 1972: Latin Punctuation in the Classical Age, The Hague.

Con arreglo a las normas editoriales vigentes para las publicaciones periódicas del CSIC, se hace constar que el original de este artículo se recibió en la redacción de EMERITA en el primer semestre de 2005, siendo aprobada su publicación en ese mismo período.

EMERITA (EM) LXXIII 2, julio-diciembre $2005 \quad$ pp. 303-351 ISSN 0013-6662 